University of Rhode Island

DigitalCommons@URI

Open Access Master's Theses

2017

\title{
An Online Study of Actors, Self-Promotion, and the Personal Brand
}

Michael Gravison

University of Rhode Island, mgravison@gmail.com

Follow this and additional works at: https://digitalcommons.uri.edu/theses

\section{Recommended Citation}

Gravison, Michael, "An Online Study of Actors, Self-Promotion, and the Personal Brand" (2017). Open Access Master's Theses. Paper 977.

https://digitalcommons.uri.edu/theses/977

This Thesis is brought to you for free and open access by DigitalCommons@URI. It has been accepted for inclusion in Open Access Master's Theses by an authorized administrator of DigitalCommons@URI. For more information, please contact digitalcommons-group@uri.edu. 
AN ONLINE STUDY OF ACTORS, SELF-PROMOTION, AND THE PERSONAL BRAND

BY

MICHAEL GRAVISON

A THESIS SUBMITTED IN PARTIAL FULFILLMENT OF THE

REQUIREMENT FOR THE DEGREE OF

MASTER OF ARTS

IN

COMMUNICATION STUDIES

UNIVERSITY OF RHODE ISLAND 


\section{MASTER OF ARTS THESIS}

OF

\section{MICHAEL GRAVISON}

\section{APPROVED:}

Thesis Committee:

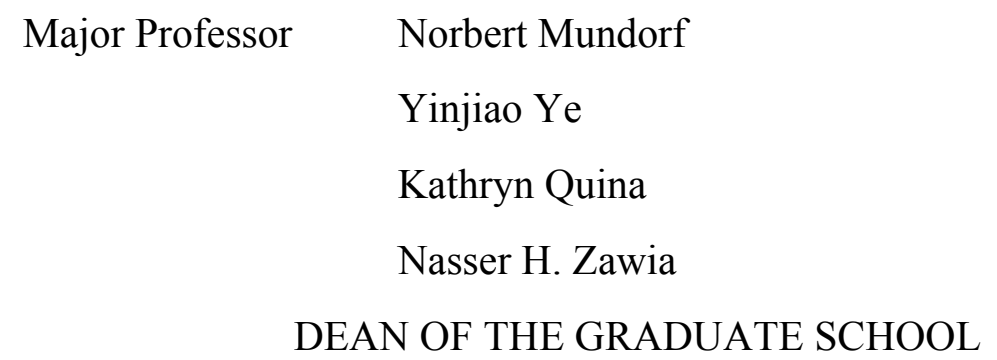

UNIVERSITY OF RHODE ISLAND

2017 


\begin{abstract}
Social media and social networking sites (SNS) allow more individuals the ability to communicate through a mass medium in a way that was once reserved for major businesses and celebrities primarily by $\mathrm{TV}$ and radio. As businesses begin to enter the world of social media, using the internet as a marketing platform to communicate their brands, along with individuals, using various sites to promote themselves professionally in the job market, the lines between business and personal are becoming increasingly blurred. Social media has become a selling platform; a platform of self-promotion as much as a means for connection. This business and personal blur is most noticeable to the working professional actor. Actors' bodies and minds are their product; their personality is their brand. Because of this, actors are more conscious of their being, identity, and the way they present themselves to this online and offline world. Using previous research in impression management, marketing tactics, social media uses research, along with online observation of actors' social media pages, this thesis seeks to explore social media sites as they are primarily used for self-promotion. I anticipate that the results of this research will find that, in the computer mediated marketing age, social media is the marketing tool paving the way for the increase of the personal brand.
\end{abstract}




\section{ACKNOWLEDGEMENTS}

I would like to acknowledge my family and Patrick for their continued support. I would like to thank Joanne DiBello for the opportunities she offered me, during my time at URI, that allowed me to continue my academic and professional pursuits, as well as Gayla Gazerro for her generous support throughout this process. I would also like to thank Dr. Leonard for joining in this journey and bringing her marketing experience to the table. And of course, a big thank you to Dr. Mundorf, Dr. Ye, and Dr. Quina who have committed their time, energy, experience, and intellect from the beginning to help make this thesis possible. Additionally, I would like to acknowledge, again, my advisor; Dr. Mundorf's continued advisement and commitment to the process. With sincere gratitude and appreciation, I thank you all. 


\section{TABLE OF CONTENTS}

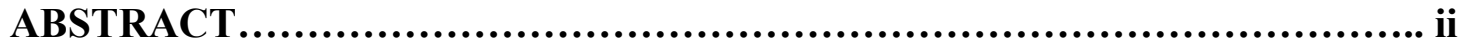

ACKNOWLEDGEMENTS......................................................... iii

TABLE OF CONTENTS....................................................... iv

LIST OF FIGURES............................................................. v

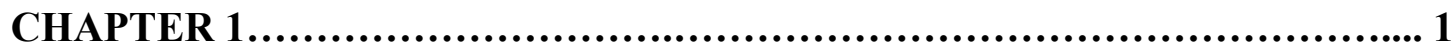

INTRODUCTION ....................................................

CHAPTER 2.....................................................................5

LITERATURE............................................................... 5

Impression Management and Social Media.......................... 5

Uses and Gratifications and Social Media............................. 6

Word-of-Mouth and Virality....................................... 13

Content Marketing ............................................... 16

Branding..................................................... 18

Personal Branding ............................................... 21

Social Media Honeycomb.......................................... 26

PESO Model........................................................... 28

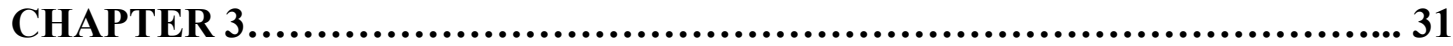

METHODOLOGY .................................................... 31

Participants.........................................................

Material.............................................................. 31

Procedure................................................................ 32

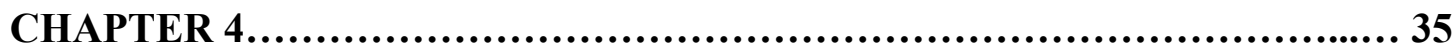

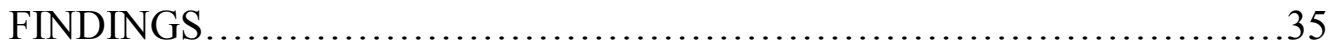

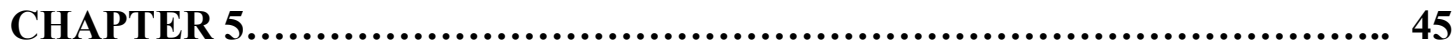

CONCLUSION .................................................... 45

Discussion........................................................... 45

Limitations............................................................ 48

Further Research................................................... 49

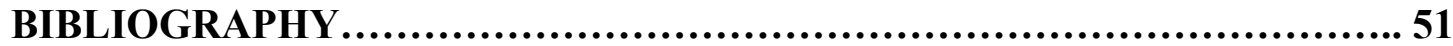




\section{LIST OF FIGURES}

FIGURE

PAGE

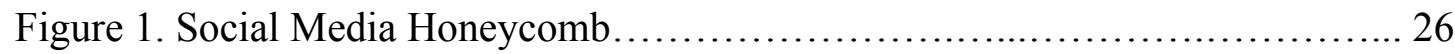

Figure 2. The PESO Model.............................................................. 30

Figure 3. An actor's intro section listing all his employment and educational associations to his acting profession................................. 37

Figure 4. An actor's intro section listing his Actors' Union affiliation as well as his recent theater employment...................................... 37

Figure 5. An actor's Facebook post promoting his official fan page................. 38

Figure 6. An actor's Facebook post promoting his YouTube project ................ 39

Figure 7. An actor's Facebook post promoting an upcoming project................ 40

Figure 8. An actor's Facebook post promoting tickets to an upcoming project.............................................................. 40

Figure 9. An actor's Facebook post promoting an image from a previous session he photographed.

Figure 10. An actor's Twitter post (tweet) promoting positive acting accomplishments.

Figure 11. An actor's tweet promoting a recent interview for publicity purposes

Figure 12. An actor's tweet announcing his role on a popular network TV show.

Figure 13. An actor's retweet from another Twitter account promoting his official acting website and his new role on a popular Broadway show. 


\section{CHAPTER 1}

\section{INTRODUCTION}

All the world's a stage, and all the men and women merely players

--William Shakespeare

We are all just actors trying to control and manage our public image. --Erving Goffman

The rise of the modern computer mediated communication in the Web 2.0 age gives way to a new platform in which people not only communicate within social networks, but are able to promote themselves and present favorable impressions of themselves within this fast moving new media. Facebook, Twitter, Instagram, LinkedIn and others create outlets for users to enhance their self-image in ways that were originally reserved for face-to-face communication, and eventually radio and television. This new $21^{\text {st }}$ century means of communication through mass social media opens the doors to research and exploration into human personal and professional presentation. In the virtual age where so much of our lives is showcased online for an expansive audience to see, awareness of impression management and self-presentation is more important than ever. Now, actions and words live forever thanks to the internet and emergence of social media. Today's social media users are savvy when it comes to their ability to use the technology, but to what extend do they promote professionally positive self-imagery that they can use to enhance their self-interests? 
In the $21^{\text {st }}$ century, computer mediated communication has grown to incorporate many different elements that include personal relationships as well as professional promotion. The medium facilitates connection that is both intimate and vast. The rise of social networking sites (SNS) such as Facebook, Twitter, and others has created a platform for individuals to connect with one another on a personal level in a public media setting (boyd \& Ellison, 2007), like when people turn to the internet to find love (Ellison, Heino, \& Gibbs, 2006). Additionally, on a professional level, dozens of books have been published to help organizations promote themselves online; businesses are even using social media sites like Facebook to research applicants during the hiring process (Brown \& Vaughn, 2011). And even future world leaders rely on the new medium to send information to future voters (Zhang, Johnson, Seltzer, \& Bichard, 2010). Because of this, the role of Erving Goffman's (1959) self-presentation and impression management is more crucial than ever when it comes to the content users chose to promote online. As businesses begin to enter the world of social media with marketing tactics to sell their brands, the lines between business and personal are blurred. Social networking sites have become a selling medium (Edosomwan, Prakasan, Kouame, Watson, \& Seymour, 2011). The individual now has access to a mass medium that was once reserved for radio personalities and television stars. As a result, individuals are required to be more conscious of their being, their identity, and the way they present themselves to the world.

In the following study, I seek to explore the extent to which a specific group of social media (or social networking site or SNS) users utilize sites like Facebook and Twitter as a means of self-promotion. The research implemented explores the social 
media habits of theatre, TV, and film actors, whose professional image directly correlates with their private image, as a means to understand the extent to which these actors use social networking sites, and how they present themselves to the traditional fan or viewer. It is hypothesized that the actors rely heavily on the image they present on social media as is relates to their profession. Social media users are growing more conscious and self-aware of their online content and self-presentation (Labrecque, Markos, \& Milne, 2011). The purpose of using the actor is to note how closely the professional and personal image are related. If a social media user has a closely related professional and private image, then he will be more apt to manage the favorable selfimpression he presents on social media (or SNS) sites. The significance of this study is to bring awareness to the fact that the increased presence of social media is blurring the lines between business and personal lives. The popularization of today's entrepreneurs is another example of this relevance (Marwick, 2013). We are seeing the emergence of self-branding and the creation of the personal brand in everyday life.

Using observation and analysis of individuals' Facebook posts, I explore social networking sites as a means of self-promotion and personal branding. My observation examines the extent to which the user utilizes social networking sites to form his online impression. My research incorporates professional actors as subjects to gain a better perspective of this blurred line between business and personal impression management. This thesis further incorporates theories of impression management, uses and gratifications, as well as the concepts of branding, online virality, word-of-mouth (WOM), and social media use by businesses for marketing purposes as it seeks to gain 
a better understanding of $21^{\text {st }}$ century social media users as they establish themselves as a personal brand.

RQ 1 How are Facebook and Twitter used as a tool for the creation and maintenance of a professional image?

$R Q 2$ How is this professional image used to form a personal brand?

It is the goal of this paper's contribution to the field of communication to better understand how social media sites are utilized beyond the need for connection and communication between people. As the $21^{\text {st }}$ century ushers in the need for individuals to have a more public presence in the job market because of the increased competition among employers, and the fact that one third of today's workforce is self-employed (Wheeler, 2003), a guided interpretation and understanding of the importance of social media for self-promotional purposes is necessary.

Terms and areas explored: Social Media (Social Networking Sites), Word-of-Mouth (WOM), Virality, Branding, Personal Branding, Content Marketing, Impression Management, Self-Presentation, Uses and Gratifications 


\section{CHAPTER 2}

\section{LITERATURE}

\section{Impression Management and Social Media}

Impression management, popularized by sociologist Erving Goffman (1959), is the effort to control or influence other people's perceptions as we try to make the perception consistent with our goals. Goffman likens his approach to an actor on stage. In short, we act a certain way so that we may give off the impression we want an audience to conclude about us. Now imagine the internet, or more importantly, social media, us our stage. The impressions we want to present to an audience, that we act in front of, online is no different than if we were in real life with this audience. Within social media, much like real life, impression management plays an important role; we use the medium to generate the impression we wish to present to this outside audience. It is this concept that is valuable in analyzing self-promotion and personal branding within the medium. Previous research in the areas of impression management, selfpresentation, personal branding, and social media motivation exists, but is limited when it comes to understanding the social networking site (SNS - i.e. social media) user as a personal brand-maker. The world of social media and its users' interaction for connection has been explored previously by boyd and Ellison (2007), whose popular work on social media attempts to define the medium, explore its user's motivations and further understand social networking sites' expansive reach and value from the individual to the global. Additional research conducted on the subject of impression management on social media dating sites by Ellison, Heino, and Gibbs (2006) determined that favorable impressions and credibility were most important when 
presenting oneself online. Kramer and Winter (2008) also studied impression management by way of social media and found that there was a link between online communication and extraversion. Another link between self-esteem and the types of social media use were also explored in this same study. The effects of the "Big Five" traits (openness, conscientiousness, extraversion, agreeableness, and neuroticism) on Facebook in undergraduate students was the focus of a study that determined loneliness correlated to higher amounts of Facebook friends leaving the remaining four traits to have little impact on social media use (Skues, Williams, \& Wise, 2012). Additionally, research on self-presentation uses on social media examined personality traits and secondary goals as predictors of behavior on Facebook (Rosenberg \& Egbert, 2011) as well as the differences between self-presentation and self-promotion on Facebook and LinkedIn, and how promotion and branding has become a "normalized, accepted phenomenon in ordinary people's lives" (Van Dijck, 2013). As explored above, previous research in regards to social media uses and presentation is varied, however social media motivation as it concerns self-promotion as a personal marketing technique has been limited.

\section{Uses and Gratifications and Social Media}

An examination of the theoretical framework of uses and gratifications has sparked renewed interest thanks to social media in the last ten years. As Katz, Blumler, and Gurevitch (1973) initially concluded in their seminal work, individuals use mass media to seek gratifications and feel connected to others. Through this research, it is assumed that the users are active, and in the process involving mass communication, there is initiative to linking media choice and needs taken on by the audience member. 
Needs are derived from social situations and the gratifications of these needs are derived from three main sources including the media content, exposure to the media, and the social context that typifies the situation (Katz et al., 1973). To understand uses and gratification as the theory applies to social media is to understand the importance of the medium as a source for connecting, maintaining impressions, and information getting; it is to also understand that value of social networking sites, as increasingly popular media with an increasing usage. A thorough understanding of the social media's history, as well as asking the question: to what extent do people use social media as a source of information getting, will help to establish the value of the medium as a tool for selfpromotion and personal branding. Uses, gratifications, and social media research extensively came from Wilson, Gosling, and Graham (2012) when they examined 412 relevant articles on social networking sites written between 2005 and 2011. The authors sought to explore among other things, descriptive analysis of users, the motivations for using Facebook, and the role of Facebook in social interactions. This previous research helped answer the questions: why people used social networking sites, but it did not go too in depth as to explore why these users choose to post or share specific online content (to self-promote, for example). Adam Joinson (2008) categorized seven unique uses and gratifications for using Facebook: social connection, shared identities, photographs, content, social investigation, social network surfing, and status updating. Additional research into motivational behaviors behind online posting and sharing comes from the New York Times Customer Insight Group (2011), who published an article titled The Psychology of Sharing. Why Do People Share Online? The CIG's methodology for the study consisted of three parts: in person interviews, a one-week sharing panel, and a 
quantitative survey of 2,500 online sharers. The CIG pinpointed five motivational factors for sharing content: to bring valuable and entertaining content to others, to define oneself to others, to grow and nourish relationships, self-fulfillment, to get the word out about causes or brands.

It has not gone unnoticed that the rise of the internet among users worldwide has revived invested interest in the theory of uses and gratifications in the $21^{\text {st }}$ century. The 90s proved a tipping point for the medium. In the ten years from 1992 to 2002 the amount of internet users jumped from 12 million to 550 million (Rogers, 2010). Social networking sites like Facebook and Twitter have become dominant channels for connecting and communicating over this medium. The Pew Research Center reports that in 2013, 72\% of adults use some form of social media (Brenner \& Smith, 2013). These numbers prove that the cyberculture is growing at exponential rates throughout the world thus making computer mediated communication a more relevant field of study. Only a few years ago when social media research was still in its early stages, Thomas Ruggiero (2010) accurately predicted its overwhelming importance by saying, If the Internet is a technology that many predict will be genuinely transformative, it will lead to profound changes in media users' personal and social habits and roles. The Internet's growth rates are exponential. The number of users has doubled in each of the last 6 years. If this development continues at the same rate, the Internet will soon be as widely disseminated a medium in daily usage as television or the telephone. (p 28) 
To continue this understanding of social networking sites and uses and gratifications, research by Raacke and Bonds-Raacke (2008) found that college students used Facebook and Twitter for significant amounts of time to keep in touch with old friends, meet new friends, and learn about events and functions, thus meeting a need for connection and information gathering. This ultimately supports Ruggiero's (2000) claim that, "the individual's desire for information from the media is the primary variable in explaining why media messages have cognitive, affective, or variable effects" (p. 8).

Although the previous research incorporated by the above researchers does add insight to the history and motivations of basic social media interaction, it is limited to interaction between the users within the network. The focus of my study expands on the SNS user to use the media as an outward platform (like TV or radio) for self-promotion as it relates to the formation of a personal brand. In fact, in recent years the medium has shifted from a space of self-expression, like status updates (Joinson, 2008) and place where friends connect (boyd \& Ellison, 2007), to a place where the user, understanding the importance of self-presentation has utilized the online medium as a tool of selfpromotion (Van Dijck, 2013). Marwick and boyd (2011) determined celebrities' uses for social media involves this shifting concept of social media as a means of self promotion when they examined the Twitter pages of celebrities. They acknowledged that the micro-blogging site was a valuable resource for celebrities, in that, it was a way for the celebrity to maintain their outgoing impressions personally (those who don't pass on social media accounts to managers or staff), as well as having a direct line of communication to the public. They found that social media was necessary in creating and maintaining a fan base as well as a much needed tool to maintain their celebrity 
status, and being a place where fans could personally get information from them (Marwick \& boyd, 2011).

Social networking sites satisfy further needs for information-getting by being a major resource for news today with $30 \%$ of the overall population getting their news from Facebook (Mitchell, Kiley, Gottfried, \& Guskin, 2013). Facebook, Twitter, and numerous blogs rival traditional news media when obtaining and passing along information, which was exemplified during Hurricane Katrina (Glynn, Huge, \& Hoffmann, 2012). Social networking sites have been the platforms for major cyberactivism that include anti-war and global justice causes, like those seen in Iraq, and other Middle Eastern conflicts, where activists used the internet to communicate and coordinate (Eltantawy \& Wiest, 2011). American politics have changed in the last ten years due to the role of the internet as well. From the blogs of the 2004 campaign, to the social media of the 2008 and 2012 elections, both candidates and voters alike use the medium actively to send and receive information (Zhang et al., 2010). This research shows an expanding scope of information that people actively receive online. As a medium used for personal connection, self-expression and news gathering, the medium further expands its scope as a platform for self-promotion. The user's ability to be a successful self-promoter is only as good as the methods by which he uses the medium to strategize his promotional agenda. It is to his benefit to understand the important aspects of information travel through social media. Furthermore, what makes social media such an appealing platform for the actor, in particular, is its ability to connect directly with other people en masse. Social media is a global medium at the hands of the individual. Arguably the most valuable use of social media is the rate at which 
information travel. This is primarily done by way of word-of-mouth (WOM) and content virality. The ability to utilize word-of-mouth (WOM) as a favorable marketing tool, and content virality, which has proven to be advantageous to brands (Drury, 2008) online, gives the actor a stage to promote himself alongside business giants who are using the same strategy.

Social media usage continues to grow around the world, and with the increase of users, comes the variety of ways in which people use the platform. Most recent updates from the Pew Research Center show 79\% of online adults use Facebook, 32\% of online adults use Instagram, and 24\% use Twitter (Greenwood, Perrin, \& Duggan, 2016). These online platforms continue to increase in popularity as a way to communicate with friends and associates, as well as for other uses. News and shopping are two other increased uses for the social networking sites. Additionally, according to recent Pew research, $62 \%$ of social media users get their news from the sites. Facebook users get their news $66 \%$ of the time, and Twitter users get theirs $59 \%$ of the time (Gottfried \& Shearer, 2016). This one stop shop approach to information also applies to consumerism as well. Shoppers are finding increased inspiration through social media year over year (Holiday Shopping Goes Social, 2014). Recent data has shown that in 2014, $64 \%$ of holiday shoppers used social media for gift ideas. This was an increase from $51 \%$ the year before. By comparison, traditional media dropped with $45 \%$ of gift ideas coming from TV (down from $54 \%$ the previous year), and $26 \%$ of inspiration coming from magazines (down from 35\%).

From a professional standpoint, the need to keep a professional and positive appearance online as increased in importance with $91 \%$ of employers saying the 
screened potential employees through social networking sites; $76 \%$ on Facebook alone (Van Dijck, 2013).

This increase of personal usage has not gone unnoticed by businesses who have increased their presence on social networking sites considerably over the last five years. According to Facebook's own data, over 50 million small business pages can be found on the platform (Chaykowski, 2014). Business are quick to adopt the media as a tool to not only to advertise to consumers, but to communicate with them as well. The ability for a business to have direct conversation with its consumer base affords social media an advantage that cannot be utilized with traditional media like TV or radio. As Kietzmann, Hermkens, McCarthy, and Silvestre (2011) appropriately posit:

With the rise of social media, it appears that corporate communication has been democratized. The power has been taken from those in marketing and public relations by the individuals and communities that create, share, and consume blogs, tweets, Facebook entries, movies, pictures, and so forth. Communication about brands happens with or without the permission of the firms in question. (p. 242)

As more and more people enter the world of social media, the need to reach, communicate, and market to these people will continue to grow as well. Marketing is no longer considered one-dimensional in that it sets out to deliver a message. In the $21^{\text {st }}$ century Web 2.0 climate, social media makes marketing interactive (Drury, 2008). Because of this, the market interest for social networking sites is ripe for the entrepreneur-- and ultimately-- the actor looking to reach a wide range of people through 
a mass medium. Therefore, two elements of value for the online marketer-- in this case, the actor-- are word-of-mouth (WOM), and viral communication.

\section{Word-of-Mouth and Virality}

Word-of-mouth is considered by some to be the most valuable form of marketing. It is the most trusted, and most likely to drive sales. In fact, according to Nielsen, $92 \%$ of consumers trust recommendations over all over advertising, and $64 \%$ of marketers say it is the most effective form of marketing (Whitler, 2014). When examining brand interaction on Twitter, a study found that $80 \%$ of tweets involving brands were to gather information about them or to share this information to others (Midha, 2014). In fact, social networking sites as a whole allow for both word-of-mouth marketing and viral marketing to be more effective than traditional media platforms because the growing number of direct product and platform engagement (Castronovo \& Huang, 2012). Word-of-mouth communication online is valuable for the marketer because it leads to the phenomenon known as virality. This relatively new concept of viral marketing posits that social media users will promote content by sharing it with each other, allowing it to reach millions of users with little or no effort from the creator, marketer, or in our case, actor.

Motivational factors determining what people post online has to do with how far they want the information to reach. When concerning entrepreneurs, or businesses, or actors using social media to promote their agendas the further the better. In understanding concept that social networking sites are used as a mass media platform for self-marketing purposes it is important to understand the extent to which information spreads. Recent research as to what makes information or ideas go viral have examined 
the role of the communicator (or influencer), the community (or network) or content itself; all with varying results. When looking at innovation diffusion from a more modern standpoint one can look at adoption using communication channels of the $21^{\text {st }}$ century, i.e. social networking sites (Facebook, Twitter, et al) and other computer mediated communication forms. According to Rogers (2010), the internet reached critical mass around 1990. In the ten years from 1992 to 2002 the amount of internet users jumped from 12 million to 550 million (Rogers, 2010). Social networking sites like Facebook and Twitter have become dominant channels for connecting and communicating over this medium. The Pew Research Center reports that in 2013, 72\% of adults use some form of social media (Brenner \& Smith, 2013). These numbers prove that the cyberculture is growing at exponential rates throughout the world thus making computer mediated communication a more relevant field of study.

The value of social media for the actor comes in its ability to spread information to massive groups of people simultaneously or slowly through a group similar to a virus. This concept of virality is becoming more popular a term within the cyber culture. We are always hearing things "go viral." Propagating the idea of virality is a study by Weng, Menczer, and Ahn (2013). Information spreads like complex contagions amongst a single community due to structural trapping and homophily thus causing multiple exposures throughout that community. Viral memes that infect multiple communities act like simple contagions in that each exposure has the same probability to infect an individual. Weng, Menczer, and Ahn concluded that community structure and the information that is shared around it and through it play a significant role in information 
or meme's virality. However, other research conducted argues that community has less to do with virality, and that the content stands on its own to propagate.

This research argues that the content itself plays a large part in its virality when sharing information through the internet. Berger and Milkman's (2012) study on virality examined the effects emotions had on sharing stories online. Berger and Milkman looked at how many times New York Times articles were shared over the internet. The more the story was shared the more likely it was to go viral. The results of their research concluded that positive emotions more likely resulted in stories being shared over the internet over negative. Berger and Milkman also concluded that higher activated (aroused) emotion i.e. anger and anxiety were more likely to cause a story to be shared, and ultimately go viral than a low activated (arousal) i.e. sadness. In another study, Guerini, Strapparava, and Ozbal (2011) argued that the content itself and not the influencer is the cause of information going viral. Additionally, researchers concluded that when content invoked curiosity and mystery (among other attributes) the content was more likely to be shared.

Recent examples of content going viral through the internet prove that information spreads rapidly through cyberculture similarly to a virus or contagion. This notion of virality is also prevalent in the world of marketing and advertising. Even the term viral marketing is commonly used in the business.

Virality as a marketing innovator also relies on the user or consumer to replicate the messages surrounding the product by sharing this information with friends. Facebook, Twitter, and others are the channels that allow the subjects to pass along a message. Roger's subsequent research over the last forty years has both proven the 
persuasive power of the individual's replication. In a recent New York Times article, Teddy Wayne (2013) says advertisers are adopting to the internet as a channel for product presentation. According to Wayne's article, the popular Old Spice Man commercial had over 47 million views online in 2010 which mostly occurred through people posting and sharing the ad through social networking sites.

Other examples of internet virality can be seen in the world of politics and their recent entrance into the world of social networks. In the 2012 presidential election, memes relating to candidates appeared all over social networking sites. They were used to point out a candidates' integrity, and awareness to the issues central to the campaign. Two such viral contents, or memes, that invaded the internet during the presidential debates and centered on the candidates were the "binders full of women" and the "horses and bayonet" memes. For example, when Mitt Romney claimed he was given "binders full of women," Twitter processed up to 104,704 tweets per minute. As a result, a Romneysbinders Twitter feed, blog site and Facebook page with over 245,000 likes emerged (Peralta, 2012). The second meme formed out of a debate when Barack Obama used the term "horses and bayonets" to counter argue a Romney criticism. The first Tumblr parody page to be created took nine minutes to infect the internet. By the end of the debate online content involving Obama's "horses and bayonets" could be found on three Twitter accounts, two Tumblr pages, and a standalone website (Estes, 2012).

\section{Content Marketing}

The use of the internet as a marketing tool is seen most prominently through the cultivation, and execution of content marketing. This form of promotion, although it has been around for centuries, utilizes the internet, and more valuably, social media to its 
success. The idea of content marketing is not a new concept. Content marketing has been around for centuries. Benjamin Franklin's Poor Richard's Almanack is the earliest known American version of content marketing, where the founding father used the magazine to promote his printing business (Pulizzi, 2016). Since then, print, radio, television, and now the internet has been sources of the popular promotional method. Magazines dominated the 18th and 19th century in terms of content vehicles. Johnson \& Johnson, John Deere, Michelin, Jell-O and others distributed their own content through the magazines and various books. The advent of radio and TV gave way for content to be streamed on air, most notably Proctor \& Gamble, and the rise of the "soap opera" (Pulizzi, 2016).

According to the Content Marketing Institute, it was not until 2001 when Penton Custom Media began using the term "Content Marketing." The idea went viral between 2008 and 2012 with businesses shifting their marketing strategies towards content. In 2011, L'Oreal bought makeup.com to re-launch it as a content platform and in 2012 Kraft began focusing its entire marketing department around it (Pulizzi, 2016). Marketing and business scholars took notice and began researching the concept including Nina Koiso-Kanttila (2004) who compared digital content to that of traditional products and services through the marketing construct known as the 4P's: product, promotion, place, and price. Koiso-Kanttila's work was, later expanded upon by Jennifer Rowley (2008) who sought to differentiate digital content from that of the traditional.

The real value in content marketing for the actor has to do with its ease of creation, ease of distribution, and inexpensiveness. The barriers of traditional content 
marketing no longer exist in the digital age. A brand of any size can reach customers, the talent that creates the content does not necessarily have to consist of professionals, and the technology today allows for anyone anywhere to publish content (Pulizzi, 2012). Storytelling is considered to be at the center of content marketing, with companies like Coca-Cola putting storytelling at the center of their future marketing initiatives as more and more brands are realizing that the technology to promote themselves is worthless without a content marketing strategy (Pulizzi). There is no doubt of the importance for content marketing in the 21 st century climate. It is generally agreed upon that not only is it the wave of the marketing future, but companies need to consider implementing it as part of their marketing strategy as it has shown to increase brand health which plays a large part in maintaining the brand in the long term (Ahmad, Musa, \& Harun, 2016).

The rise of content marketing is prime with opportunities for the actor to promote his brand through the 21 st century medium. The actor is the creator of his own content. His ability to promote it through social media is relatively inexpensive, and by using social media as the platform he is able to offer a direct link to additional content such as tickets to a show or station info for his TV appearance. Social media allows him to target an audience directly and because the medium is interactive, he can communicate directly with interested parties rather than push information through oneway channels as is done in traditional media (Rowley, 2008). This intimate, interactive, and inexpensive way to share content makes the actor an ideal marketer of his brand.

\section{Branding}

Branding has been a part of human culture going back to the first century A.D. with the origin of the word "brandr," an ancient Norse word, meant "to burn." It was in 
the 1500s however that the term was used to label the act of marking cattle for ownership (Shadel, 2014). In the 1820 s mass production altered the meaning to refer more to a product or good's quality rather than ownership, and in the 1870 s with the ability to register trademarks, companies could not copy products, this making the brand part of companies' lexicons (Shadel, 2014). Gaining popularity among in the early 20th century, branding began showing up more and more among the top three consumer behavior journals (Moore \& Reid, 2008). In the 20th century the brand became more than product or a name. The brand became associated with the consumer's emotional connection with the product and the overall reputation of a company associated with the goods and services. David Ogilvy, founder of the world's largest advertising, marketing, and PR companies said the brand was "the intangible sum of a product's attributes" (McLaughlin, 2011). It was this idea that the brand became a larger entity than the product itself. Probably the most notable of the original brands as we know it today is Coca-Cola and the way they distinguished themselves from their competition with a recognizable logo, slogan, campaign and quality product (Shadel, 2014). With the rise of mass communication and the continued expansion of $\mathrm{TV}$, radio, and the internet throughout the 20th and 21st century, the idea of the brand has continued to alter from products, goods and services, to a larger corporate understand and necessity, to now a more personal state (Lair, Sullivan, \& Cheney, 2005).

This very brief overview of the art of 20th the century branding paradigm shift would not be complete without mentioning the man responsible for what is considered modern public relations. Edward Bernays, called the "father of spin" and selfproclaimed founder of the concept of "public relations" (he was the first to use the term), 
was the first to utilize public opinion to promote ideas and products. As a young man he worked with the Woodrow Wilson administration to sell the public on World War I. Realizing the value in popular public opinion and the success he saw with the WWI campaign he be began to take on clients with the goal to effectively promote favorable public opinions for them (Tye, 2002). His client list included Broadway stars, General Electric, Proctor \& Gamble, CBS Media, tobacco companies, and even President Coolidge. Among Bernays' most famous campaigns (and my personal favorite) involved Lucky Strike Cigarettes. In an attempt to promote and sell more Lucky Strikes, Bernays convinced the entire New York Fashion industry to make the color of the fashion season the deep green that matched the Lucky Strike package. Bernays then devised a plan to promote Lucky Strike Cigarettes as the perfect accessory of the fashion season. The plan worked and was immensely popular (Tye, 2002). As President Coolidge's public relations advisor, Bernays sought to soften the President's hard public image by hosting a series of pancake breakfasts at The White House with the general public and Broadway celebrities. The President won re-election (Tye, 2002). This showcases, not only the origins of public relations as it pertains to marketing and promoting the brand of a major corporation (Lucky Strike), but also how the practice played an early part in the formation of a personal brand as well (President Coolidge).

As branding makes its way into the 21 st century, we continue to explore social media platforms and their emergence, not only as a dominant digital communication channel where users primarily communicate with each other, but also as the evergrowing primary platform through which consumers learn about, share information regarding, and interact with brands they consider, purchase, and evaluate (Hudson, 
Huang, Roth, \& Madden, 2016). Brand awareness has become not only commonplace in today's culture, but necessary for businesses to exist and grow. Brands have meaning to consumers, and in the internet age it is necessary for a brand to be online (Rubinstein \& Griffiths, 2001). Through the internet it is possible for a company to deliver a consistent, transparent, integrated experience where the business can understand and get to know its customers all while reinforcing its brand values (Rubinstein \& Grifiths, 2001). Integration, i.e. coordinating various promotional elements like advertising, public relations, sales promotion, to create a unified customer message, is key to successful brand management. Because the social media is essentially a hybrid component of the promotional mix, it is arguably the best, and fastest growing method to deliver these important integrated strategies (Mangold \& Faulds, 2009).

\section{Personal Branding}

We used to count business cards in our Rolodex, now we count colleagues on LinkeIn, and friends on Facebook. Why has personal branding become so important? Jobs no longer last forever. The number of self-employed individuals has increased dramatically over the last decade. A third of our workforce is now self-employed. And we are all connected 24/7.

--Alina Wheeler Designing Brand Identity

How we identify ourselves in relation to others, how others perceive us, and how we want others to perceive us all play a part in the management of or impressions. What is the story we want to tell to others, and how do we want others to perceive that story? Recently with the increased interest of social media research, scholars are looking back to Goffman (1959) and his seminal studies of self-presentation. Goffman's work posits 
that people in their everyday lives play the part they want others to perceive of them. This concept of impression management has been uncovered and re-examined with social media at the forefront. Ellison, Reino and Gibbs (2006), boyd and Ellison (2007), Marwick and boyd (2011), Labrecque, Markos, and Milne (2011), Van Dijck (2013), and others have brought a new interest to Goffman's sociological approach.

Personal branding was originally coined in a Fast Company article in which Tom Peters (1997) claimed the dot com boom allows for everyone to have a chance at becoming "a free agent in an economy of free agents." Peters argued that "the web makes for branding more directly than any packaged good or consumer product ever could." It is his idea that in the $21^{\text {st }}$ century anyone has the capacity to promote themselves through mass media communication (the internet, websites, social media) in a way that was previously reserved only for business and large product producing companies (Labrecque et al., 2011). Additional exploration of the personal brand in an essay by Lair, Sullivan, and Cheney (2005) examined parallel developments in advancing communication and organizations. They explored how personal branding is a market appropriate response and reflected on the ethical implications of personal branding as communication strategy. Personal branding has also become a subject of interest in the business world. It has been written about in Forbes, Harvard Business Review, Fast Company, New Republic, Mashable, Inc., and many others.

Soon after the rise of Web 2.0, scholar Alice Marwick (2013) extensively examined self-presentation and self-promotion in the tech community of Silicon Valley. Marwick's observations determined that self-branding was prominent among these tech workers (Marwick, 2013). Marwick asked the question: Why did people self-brand? 
She determined that self-branding was primarily viewed as a way to make more money and a necessity in technology culture, and that social media encouraged users to behave in ways that were influenced by the audience of the tech scene. Most importantly, Marwick determined that the values instilled in social media are those of the enterprise business culture. The limitation of Marwick's research is that her study subjects are limited to the tech community. She opens the door for further research by asking how self-branding might exist in other social contexts.

In the 21 st century this Goffman-esque approach to social media is only growing, and users utilize this medium to their benefit. Both personal and professional lives are presented on various online platforms like Facebook, Twitter, and LinkedIn. By using these multiple avenues effectively, the users can "shape a consistent picture of their 'uniform public self' across all platforms" (Van Dijck, 2013, p. 211)

Out of this ability to be seen on a global scale through computer mediated communication comes our necessity to control how we are perceived by others. This need to be in charge of the presentation of our personal identity gives way for the need to control all aspects of or being. This includes the clothes we wear, the items we own, the things we do, the places we go, the people we surround ourselves with, and more. These personal identifying characteristics are a reflection of our identities (Belk, 1988). This identity is scrutinized more so now because of the ability to see and be seen throughout the online community. Out of this has come the creation, exploration, and utilization of the personal brand. The consensus among scholars is that the first mention of a personal brand as we know it, came from the aforementioned Peters, who claimed the personal brand was in response to several social changes (Marwick, 2013). These 
changes included the ever changing work and cyber culture, and rise of entrepreneurialism. Self-branding, according to Marwick,

...is primarily a series of marketing strategies applied to the individual. It is a set of practices and a mindset, a way of thinking about the self as a stable commodity that can tempt a potential employer. Self-branding, the strategic creation of an identity to be promoted and sold to others, has moved beyond its origins. (p. 166)

In truth, because of the rise of the internet in recent years and the social technologies associated with it, people are able to utilize the web for branding purposes on an individual level in a way that was once reserved for major companies. On a personal level, individuals are able to utilize social media to create this online identity of themselves that can be labeled as the personal brand. And the personal brand stretches into the individual's professional life as well (Marwick, 2013).

The personal brand, in the professional world, is becoming more and more commonplace because of the ever changing business climate geared toward job-seekers raised online. Increased globalization and rapid shifting technology and rapid job turnover have created this necessity for a person to promote themselves on a professional level that they have not had to before (Brooks \& Anumudu, 2016). The personal brand, according to Brooks \& Anumudu, is a "deployment of individual's identity narratives for career and employment" (p. 24). Personal branding has long been linked to self-improvement and self-help (Lair, Sullivan \& Cheney, 2005). However personal branding is less about an internal focus on self-improvement and more about an external self-packaging where success is determined by how effectively the person 
manages and labels his skills, motivations, and interests (Lair et al., 2005). People in the professional world are utilizing this concept of the personal brand to distinguish themselves from the competition. Top level executives are using social media as way to create and strengthen new and existing relationships as well as create value for both themselves and their company (Karaduman, 2013). Employers and employees use Facebook and professional sites like LinkedIn to promote their professional self (Van Dijck, 2013). Labrecque, Markos and Milne (2011) determined that people consciously and intentionally build online profiles to maintain a brand identity. They consciously highlighted positive attributes and positioned themselves to differentiate themselves from other individuals online. Labrecque, Markos, and Milne argue that similar to Goffman's interpretation of actors selecting intentional props and costumes, the participants in the study selected specific pictures and promoted particular information about themselves reinforcing the concept of self-presentation.

Since the personal brand became such a hot topic of professional conversation, every business magazine and company has sought to help the readers to establish their personal brands. Forbes, Entrepreneur, Harvard Business Review, Mashable, Inc., WikiHow, Huffington Post, and so many more want to tell us how to establish our personal brands. There is even a How to... For Dummies. In fact, 69 million hits on the topic appear on Google, and 766,000 books including the topic can be purchased on Amazon. If the actor needs a guide to use social media to his benefit in creating a personal brand, there is plenty of options for him to study. And by utilizing a few social media conceptual models to his advantage, the actor can use the platform personally the along with the giants like Coca-Cola, and L'Oreal. 


\section{Social Media Honeycomb}

Jan Kietzmann, Kristopher Hermkens, Ian McCarthy, and Bruno Silvestre (2011) formulated seven functional building blocks for understanding social media. The idea was that as social media grew, business that were not acknowledging or taking part in this growth were running the risk of negatively impacting their reputation, sales or even future survival (See Figure 1). Their new concept created a set of "recommendations regarding how firms should develop strategies for monitoring, understanding, and responding to different social media activities" (p. 241). These seven functional blocks of social media were: 1) Identity 2) Conversations 3) Sharing 4) Presence 5) Relationships 6) Reputation and 7) Groups.
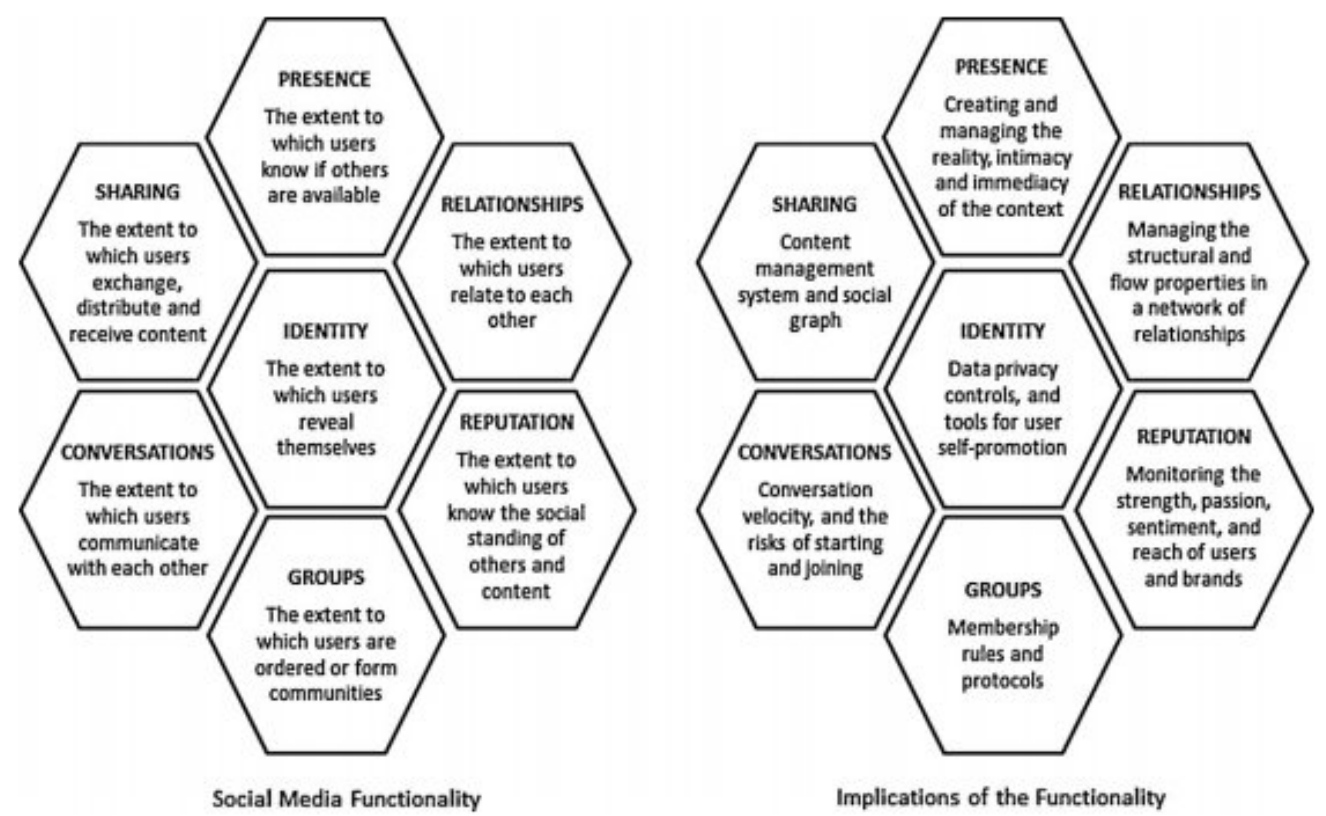

Figure 1: Social Media Honeycomb. Reprinted from "Social media? Get serious! Understanding the functional building blocks of social media." By J. H. Kietzmann, K. Hermkens, I. P. McCarthy, \& B. S. Silvestre. 2011. Business horizons, 54, p. 243. Reprinted with permission. 
- Identity is seen as the extent a user reveals his identity (age, gender, profession etc.). Identity is seen as the core of social media platforms. It asks the question, who are you?

- Conversions deals with the extent to which social media users' communication with each other. This is done through blogs, Twitter, Facebook messenger, online dating sites like Tinder all for a purpose.

- Sharing deals with the extent to which people distribute and receive content. News articles, coupons, Buzzfeed quizzes to name a few.

- Presence deals with the extent to which users know that other users are available. Are you checking in on Facebook when you go places? Is your Facebook messenger status green?

- Relationships deal with the level at which people relate to one another. Are they friends on Facebook just for the sake of having a friend, or are friends because they meet up offline as well?

- Reputation deals with the extent that a user can identify their standing with others as well as themselves. The number of followers a celebrity has on Twitter would determine their online reputation.

- Groups deals with the extent users form and communities. This can include Facebook groups, Twitter's lists that are self-created by the user or communities with shared backgrounds or invitation-only membership. (Kietzmann et al., 2011)

The researchers went further to instruct businesses to use the Honeycomb to better facilitate social media management using the Four C's: 
- Cognize- Understanding the company's social media landscape.

- Congruity- Coming up with a social media strategy

- Curate- Facilitating social media interactions

- Chase- Following the social media landscape to stay on top of the climate as it affects the business. (Kietzmann et al., 2011)

The point of the Honeycomb and Four C's associated with this, were to lay the framework for a business to use social media in a way that keeps it relevant in the 21 st century. Utilizing the methods laid out by Kietzmann, Hermkens, McCarthy and Silvestre, a business can lay out an impactful social media strategy that allows it to maintain and measure its social impact online. The importance of this model here, is to draw a link between that of a big business using social media and the actor. As the actor is himself a one-man business. His brand and his identity are one in the same. His product is his performance and the tools of social media as a method of person and professional promotion are just as valuable as that of a multi-personnel corporation.

\section{PESO Model}

Actors have to their advantage the ability to be their own publicist. Since they are their own company, product, and ultimately brand, it is best for the actor to act as his own marketing and public relations firm. Since it is considered PR is marketing, sales, customer service, and the overall communications hub, it is important for the actor to have a firm grasp of their public relations department-- them. Since the actor has social media at his immediate disposal as a cheap, efficient, and wide-reaching medium, it is the most valuable tool they have to promote their brand. A model for marketers to utilize social media more efficiently to promote their brands that is gaining attention is 
The PESO model (See Figure 2). The PESO model was devised by Gini Dietrich (2015) as a way to integrate the four main types of marketing: Paid, Earned, Shared, and Owned (Dietrich, 2015). Using these four elements of marketing in a multifaceted online social media campaign is the most efficient way to market the actor's brand. In the PESO model,

- Paid Media is traditionally thought of as big magazine, radio and TV advertising; in the social media world is means sponsored posts or social media advertising.

- Earned Media is publicity; an article about your new play, or an interview with you on the local five o'clock news.

- Shared media is social media; anything that can move between people online through various social networking platforms.

- Owned Media is content; anything that the actor or company creates for the purpose of promotion. In the digital world it lives on websites, blogs, YouTube pages and other areas of the internet where the actor may have created content for himself.

The value in the PESO model for actors is found in the actor's ability to have control over the various elements. As the actor controls his PR strategy and controls the content on his website or social media pages, he ultimately controls how the content moves between the four media. The PESO Model is widely becoming the new way in which companies of all sizes strategize their PR and Marketing (Iliff, 2014) 


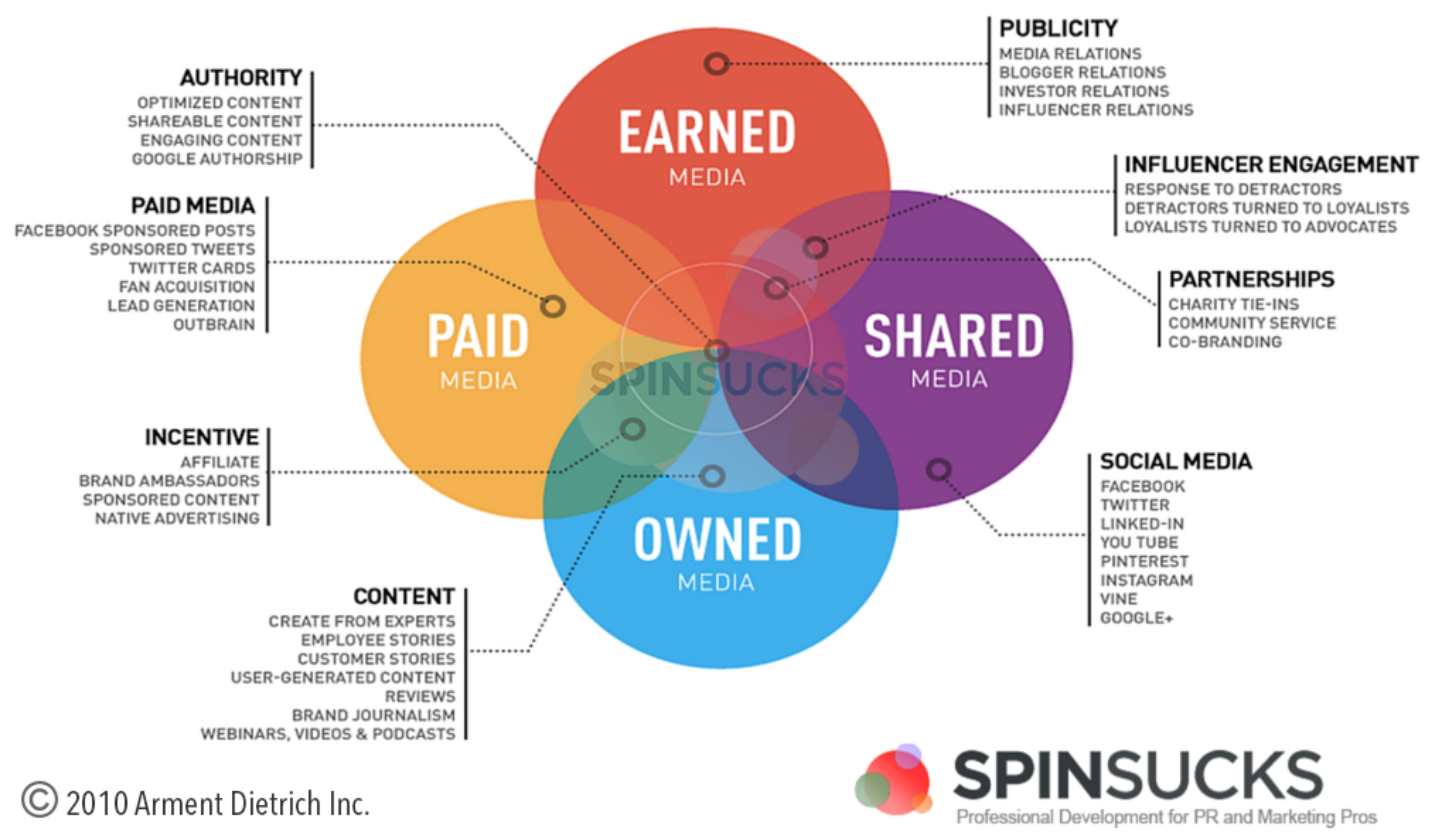

Figure 2. The PESO Model. Reprinted from PR Pros Must Embrace the PESO Model, by Gini Dietrich, 2015, Retrieved from spinsucks.com. Copyright 2010 Arment Dietrich Inc. Reprinted with permission.

In short, all the elements laid out previously are to bring a well-rounded understanding of social media, its history, and the valuable elements of its construct and usage that are, to the actor, indisputable tools for a successful campaign of selfpromotion and personal branding. By understanding how the medium came to be at present, as well as how it works day to day; what makes specific content more successful than others, and how to use that massive method of communication to the benefit of the individual, the actor can play his part from this apartment on $9^{\text {th }}$ avenue and $43^{\text {rd }}$ Street to the same effect alongside the bigger co-stars over at Madison Avenue. 


\section{CHAPTER 3}

\section{METHODOLOGY}

\section{Participants}

A sampling of no more than ten $(N<10)$ actors' public social networking pages (SNS) pages were examined. Gender was broken down into five (5) male and five (5) female actors. Ages ranged from 25-35. Race/ethnicity was not important in determining the participant but was be noted for recording demographic purposes. Participants were New York City based actors who work on stage and in film and television. Participants were not high-profile "movie stars." Participants were actors who work in regional, Broadway, Off-Broadway, and touring theatre productions, as well as minor television and film roles in NYC-based programs like Law \& Order, The Good Wife, and Unbreakable Kimmy Schmitd to name examples. The social media pages observed were controlled by the actors themselves and not through an agency, publicist, or management team.

\section{Materials}

Two social networking sites (SNS) were examined for each participant. These were public Facebook pages and public Twitter pages. The actor's age, sex, race/ethnicity were documented for research purposes but were not reported on in the findings as this information was not important when it came to determining results. It was also felt for security and enhanced anonymity that the finds would be reported as "he" and she" interchangeably.

1. When examining Facebook pages, the following content and information were examined and categorized: (a) profile photos (b) cover photos (c) photo 
posts (d) video posts (e) link posts (f) additional independent posts such as updates, comments, and quotes (g) shared content from other Facebook pages, (h) intro and/or about info.

2. When examining Twitter profiles, tweets were categorized into (a) picture tweets (b) video tweets (c) update tweets (d) link-sharing tweets (e) re-tweets (f) tweets with quotes, comments, and observational tweets. I also observed the Twitter profile and cover photos.

3. A document was used to keep track of the number of times each post falls into the specific category for organizational purposes only.

4. An additional document be used to paste screenshots of each separate post into a column with rows alongside it being used to answer questions asked of each post as outlines procedurally. This was used for documenting and organizational purposes only.

5. My personal computer was used to view these public social media sites.

\section{Procedure}

Actors were selected by me at the recommendation of professional associates within the New York City (NYC) acting community. The Facebook and Twitter profiles selected were public pages. Using a personal computer, I examined these public Facebook and Twitter pages.

1. An examination of Facebook profile pictures cover photos determined if they are used to promote themselves professionally; example questions may be, but are not limited to, (a) are they in costume (b) as the photo taken from a set (c) is the photo their professional acting headshot used on their resume 
(d) are these photos relevant to their profession (d) how does the profile and cover photo label them as a professional actor?

2. Next, using the document outlined above, it was noted how many times each post falls into the categories listed above (picture, video, link, share, status, retweet etc.). The sheet will help answer the following questions: how many of each category did each actor post? How many were related to their profession? As this study was not quantitative the resulting numbers were not used in reporting findings. They were used only as a gauge for me to determine the popularity and repetition of certain professional aspects.

3. Screenshots of posts were taken and pasted into a separate document. These screenshots were used to answer the questions: (a) is this relevant to their profession? If yes, (b) how does this label them professionally? (c) What are they promoting professionally? If no, (a) what is the user saying with this post?

4. The same process was followed for Twitter observation and analysis.

5. The data extracted from both documents along with an interpretation of the answers to the posed questions did depict an overall image of the participant helped me to answer the posed research questions regarding how Facebook and Twitter are used as tools for the creation and maintenance of a professional image.

6. Facebook and Twitter posts were examined going back as far as eight (8) weeks to obtain as much data as needed to effectively number each category 
as well as obtain enough data to answer each of the questions associated with each category.

7. In order to check the validity of observations and to avoid arbitrary interpretation, a second observer was called upon to examine key findings. This observer examined the posts labeled in each category to determine if they did, in fact, meet the criteria to be labeled accordingly. The observer determined each image and label appropriately coincided and were accurate to be reported upon with the following findings. 


\section{CHAPTER 4}

\section{FINDINGS}

The first elements of the Facebook profile examined were profile pictures, followed by cover photos, then info sections, and the users' timelines. Red carpet images, acting headshots, production photos, and images from assumed modeling jobs were the clear choices for profile and cover photos. Four of the ten actors made clear professional headshots their profile pictures. Two chose images of themselves from assumed modeling photo shoots. Two posted photos of themselves with, assumed, significant others. One selected an image of himself on a red carpet, and one selected a photo of herself in costume from a show she was acting in at the time of the observation. Of the ten actors it was observed that a majority (eight of the ten actors) preferred profile images directly relating to their acting profession or in a situation directly associating themselves as an acting professional.

Facebook cover photos tell a different story: the Facebook cover photo was introduced with the launch of the timeline, and is considered to be the most prominent autobiographical feature of the user's profile (Erickson, 2012). The cover photo is used in conjunction, as a compliment or appendix of the profile photo that encapsulates another part of the user's personality, location, profession, relationships, or interests. Of the ten actors' observed cover photos, three utilized the space to promote their profession. One actor's image was of him in a recording studio. The second was of him in assumed costume for a role, and the third was an image of a recent staged production in which the actor was currently appearing (according to her Facebook intro section). Two other actors posted photos of themselves with significant others, (these actors did 
not utilize profile pictures to do this), three actors posted scenic images (two of the New York City skyline, where the actor assumedly lives), one actor posted an image referring to a social cause (promoting equality and inclusion), and one actor posted an image of himself promoting his physical fitness (shirtless muscle flexing).

The "intro" section on the left hand side of the screen is where the Facebook user is able to tell the audience about him or herself. This section allows the user to share his location, his education, where he grew up, his past and present employment, family, relationship status, birthday and other personal details. What the actor chooses to put in the intro section of his Facebook page is telling of what he wants the public to know about him. Of the ten actors observed, all used the space to associate themselves with their profession. Four of them promoted their association with the Actors' Equity Association/Screen Actors Guild (SAG-AFTRA), the professional actors' union. Five of the observed listed previous employment, in the form of acting companies or Broadway shows they were a part is. Four of the actors listed their formal education which were all performing arts schools. And four of the observed listed their current location, which was New York City (See Figures 1 and 2). 


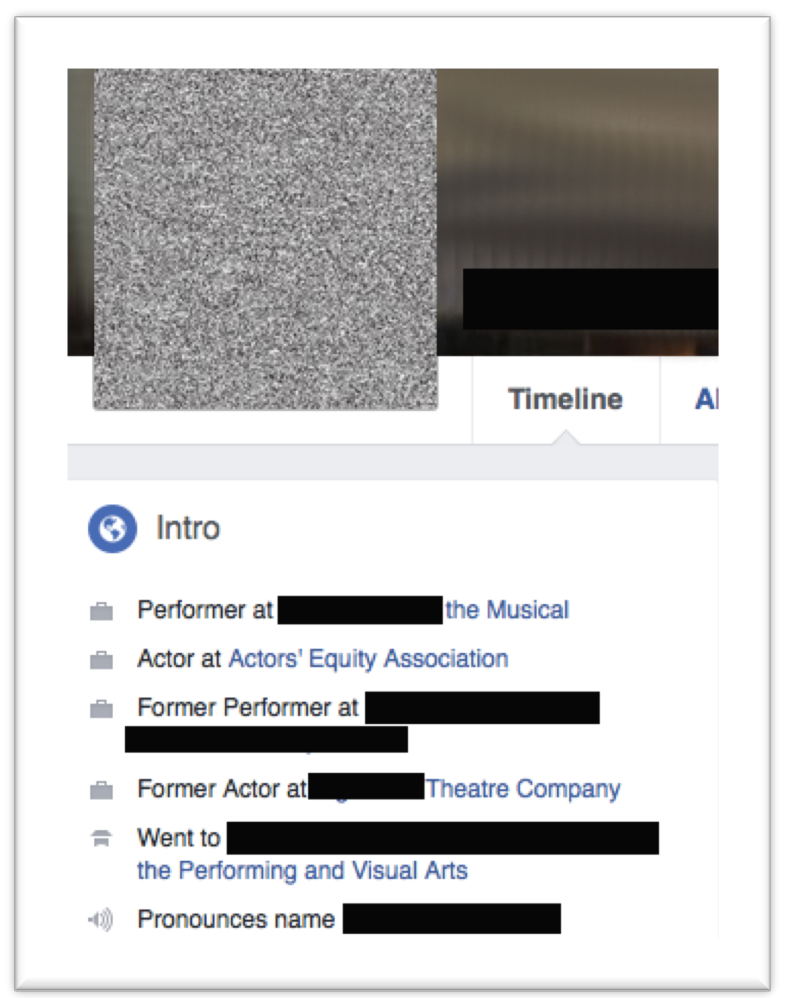

Figure 3. An actor's intro section listing all his employment and educational associations to his acting profession.

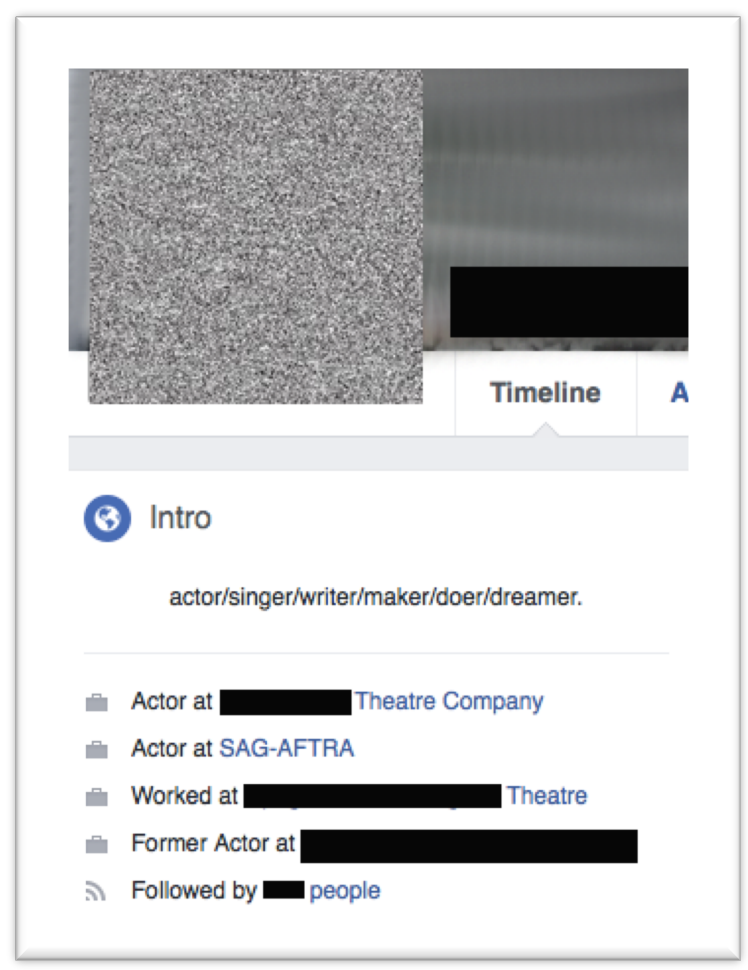

Figure 4. An actor's intro section listing his Actors' Union affiliation as well as his recent theater employment. 
Over the course of the eight-week period, the users' Facebook pages were observed, users did not post every day, and some days users would post two to three times. If there was a commonality among the users' overall Facebook timeline, that trend was the subject of the multiple posts in one day. For one user it was a show he was presently in. For one user is was photos of his recent wedding, and for two users particularly it was affirmation of their political views. Observing actors' social media pages during a political season, especially one as polarizing as the presidential election of 2016 created challenges in obtaining a professional view of the participants. I will speak to this later.

Actors continued to use the medium to promote their professionals predominately. On average, posts related to the actors' profession made up over $50 \%$ of their total posts. This included letting fans and followers know if upcoming events as well as directing them to outside websites to learn more about their upcoming projects (See Figures 5 and 6). Other types of posts that were also found on the users' Facebook timelines were pictures and videos with friends and family, political related posts, and cause-related posts (having to do with a cause or charity that was important to the user). User's also promoted their side projects and secondary jobs. Additional content on Facebook timelines included pictures with their animals if they had pets, and inspirational posts that included, quotes, or other words of wisdom.

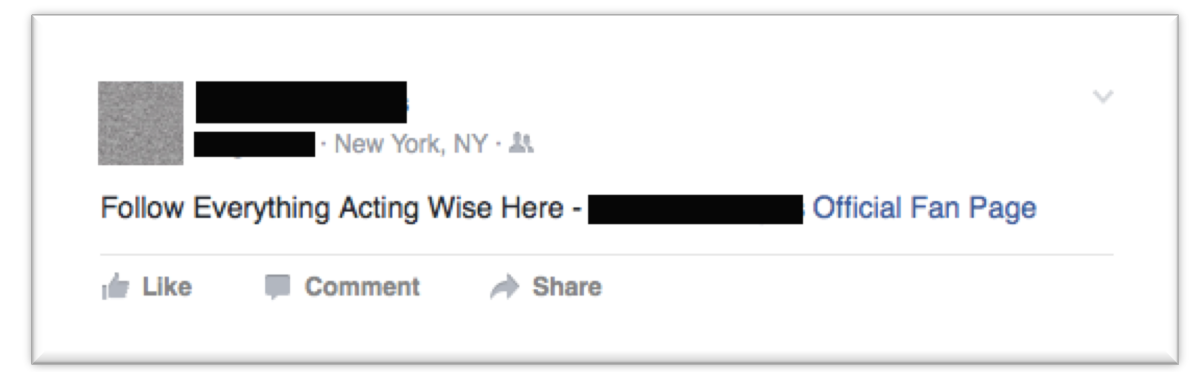

Figure 5. An actor's Facebook post promoting his official fan page 


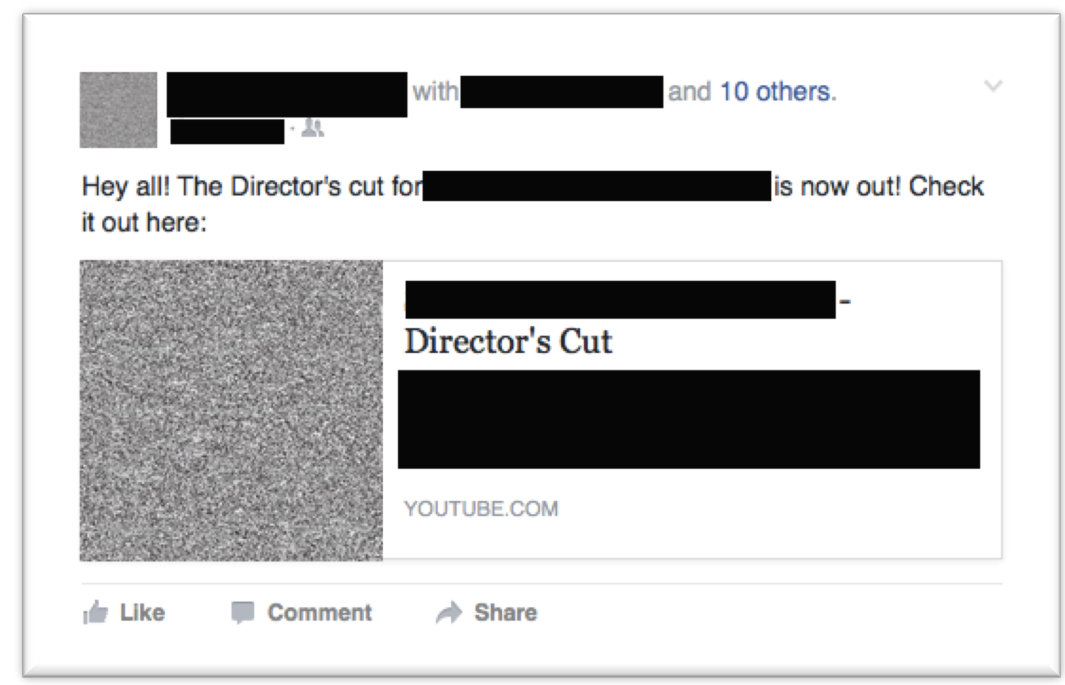

Figure 6. An actor's Facebook post promoting a YouTube project he was in.

In addition to promoting their acting professions, users promoted secondary professions, primarily ones that also promoted the individual's' creativity. Three of the actors observed were in musical bands, and these three actors used the medium to promote images of themselves with their bandmates, videos of previous performances, music videos, photo shoots, and upcoming concerts and engagements (See Figure 7 and 8). One of the actors had a full length album produced and he used Facebook to promote links to iTunes where fans, and followers, could download individual tracks as well as the full length album. As the album went higher on iTunes top downloaded list, the actor used Facebook to show gratitude, and appreciation as well as publicize the albums continued success. 


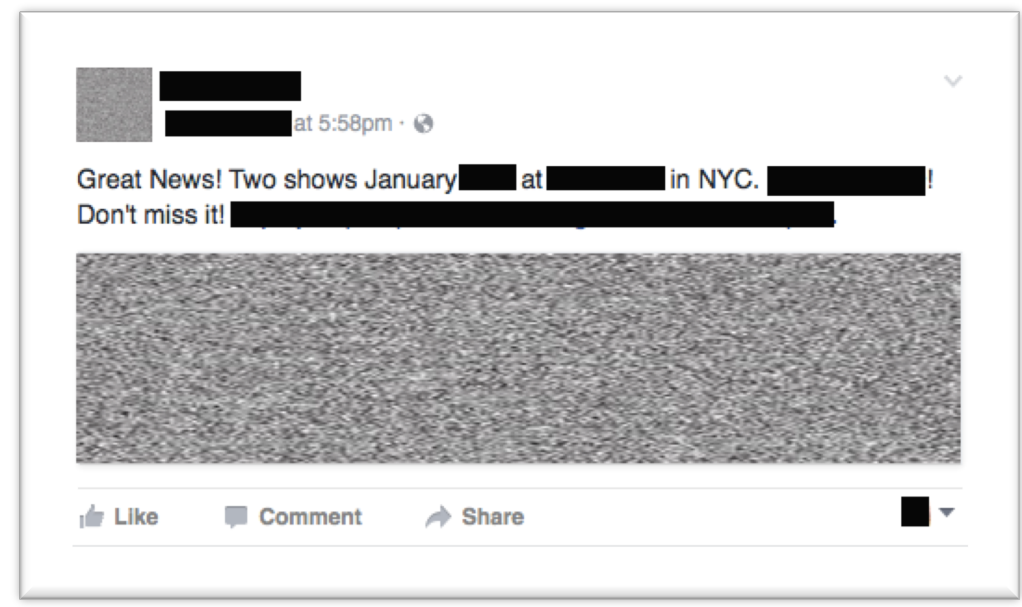

Figure 7. An actor's Facebook post promoting an upcoming project.

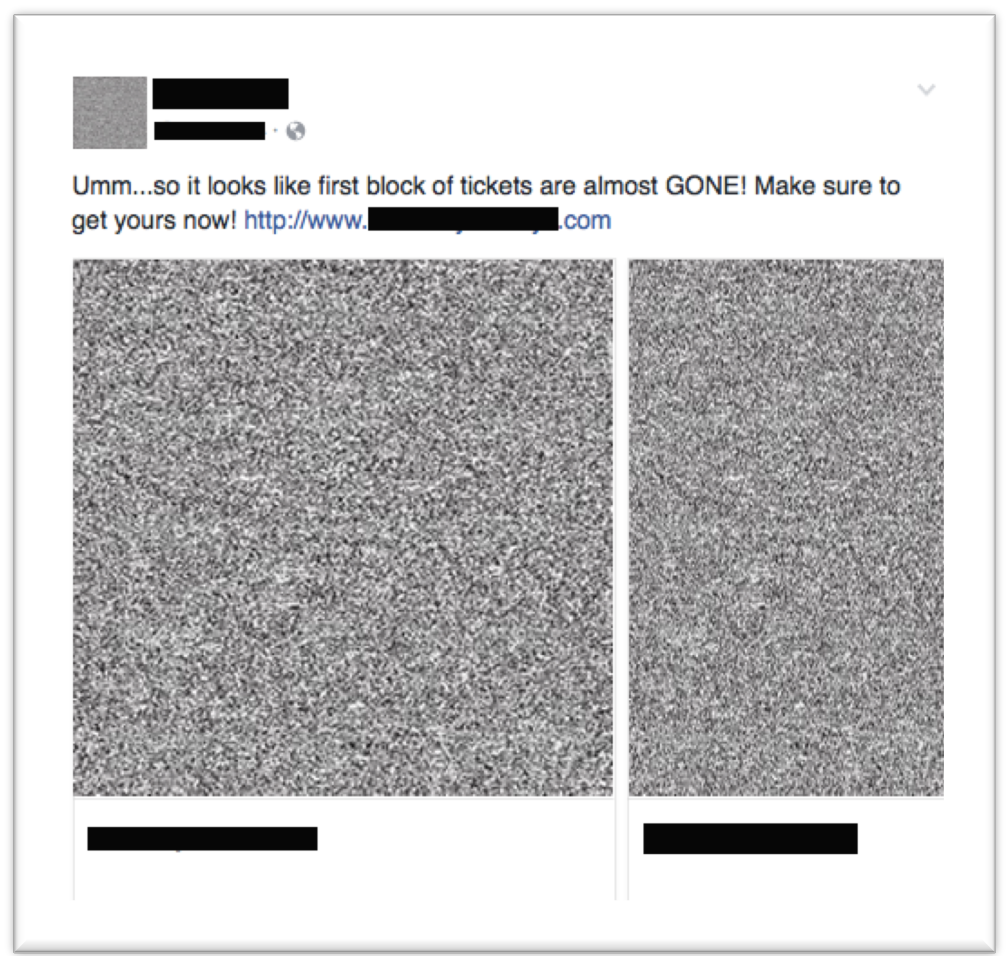

Figure 8. An actor's Facebook post promoting tickets to an upcoming project. 
One actor who also pursued a professional photography career used Facebook to promote his business. He shared albums of previous photography sessions with clients to exemplify the type of photography He did: headshots, engagement photos, family portraits were the primary. The actor also posted various images from previous studio shoots, rates and availability for future sessions for people interested in contacting him to set up a future photoshoot (See Figure 9).

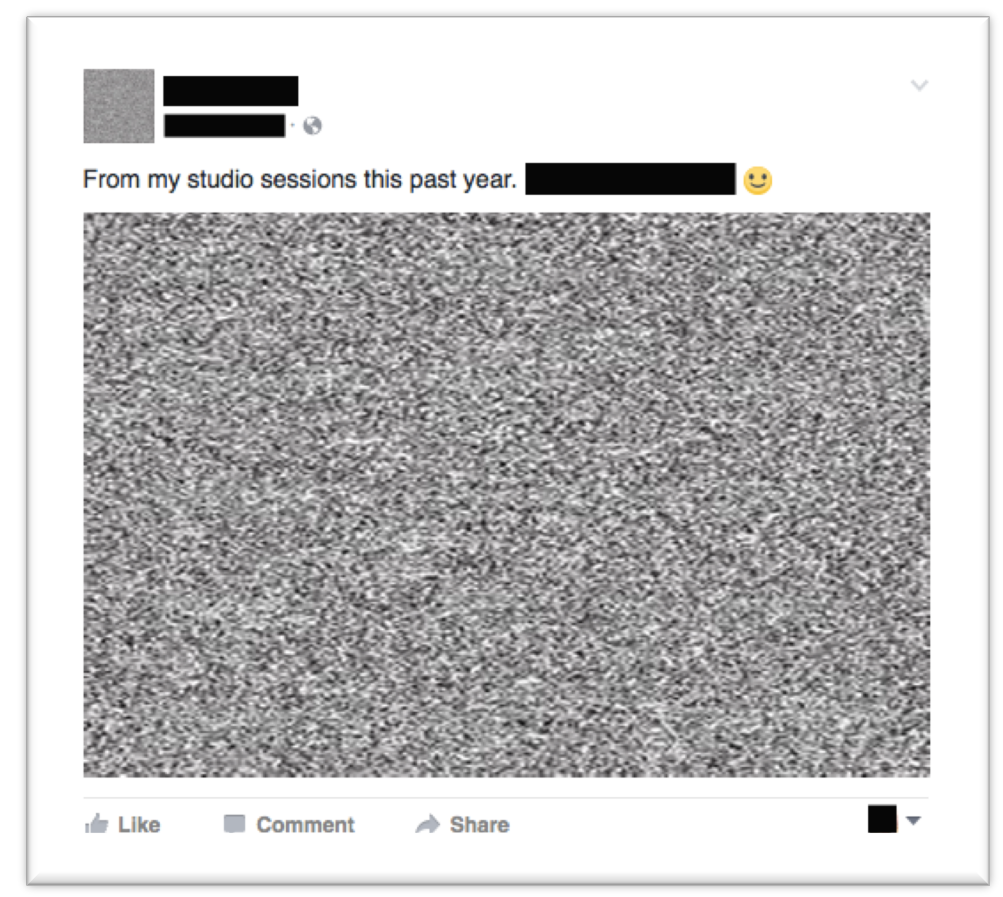

Figure 9. An actor's Facebook post promoting an image from a previous session he photographed.

Similar to the actor-photographer and the actors-musicians, two actors used Facebook to promote their physical health as support to their side-professions as physical fitness personal trainers and gym instructors. These two actors promoted the dates and times they were instructing specific aerobic classes at their different gyms to encourage fans and followers to sign up. They also shared a number of posts of them in 
gym attire showcasing their bodies, again, as support of their physical fitness, and important attribute for the working actor.

Twitter, similar to Facebook, is a social media platform considered a microblog; the platform uses only 140 characters to allow users to promote themselves, their views, and the world around them (Marwick \& boyd, 2011). The medium is popular among celebrities and politicians as a way to make statements on a particular subject. The medium differs from Facebook in that it its content is reduced to fall into the 140character limit. Although, Twitter does allow photos, videos, and links, they are condensed to meet the length requirement of the post put forward by the medium. Of the ten actors observed on Facebook nine of them also had Twitter accounts which were observed.

Of the nine actors observed, three of them used professional headshots as their profile pictures. Two actors used images from a professional photo shoot. One actor used a picture of himself on a film set holding a script in hand. Three actors used casual and candid images of selves not looking at the camera, but in the moment in the situation in which their photo was taken (one at a wedding, one on a beach, and one on the streets of NYC). Of the nine actors, three of them used the same profile picture as their Facebook page which plays to consistency throughout the two media.

Cover photos on Twitter showed a balance between professional and personal. Five of the nine actors used acting-related images as their cover photos while four used personal images. The acting related, professional images included one actor's headshot, one actor's musical album cover image, an image from a professional photo shoot, and two images of the interior of a theatre (one of the stage and one of the empty house). Of 
the personal Twitter cover photos, one was of the participant and her husband, one was of the participant's dogs, one was of a bouquet of flowers, and one was an image of a bicycle. The personal images could be interpreted as images that hold importance to the users. All of the images on the Twitter pages projected a positive image of the participants. The actors who chose to use headshots and other professionally related images for headshots and cover photos continued the use of the medium for the enhancement of their professional image as actors.

When observing participants' Twitter pages, once again, promoting the actor's profession was highly noticeable and prominent. Six of the nine actors observed used the medium to promote their career in most of their posts. These actors shared pictures of themselves in costume, posted pictures of themselves on set, and recording in studio. They also shared videos of commercials they appeared in, promoted the TV or Broadway schedule for a show they were appearing in, informed followers of an audition status or a job they booked, and shared pictures from other Twitter accounts from companies posting the ads for items and good they were hired to sell, and retweeted other accounts that mentioned them (See Figures 10-13). The other four actors used the medium to promote politics more than on Facebook. They used Twitter to retweet other accounts that supported their views as well as items with which they took issue.

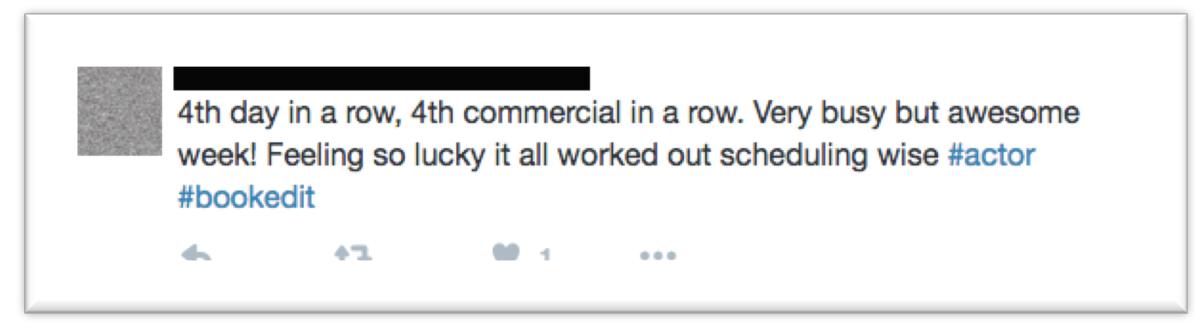

Figure 10. An actor's Twitter post (tweet) promoting positive acting accomplishments. 
This was such a fun interview with @ Check it out if you haven't

4

나

$. \mathrm{com} /$

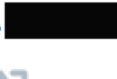

○ 8

$\cdots$

Figure 11. An actor's tweet promoting a recent interview for publicity purposes.

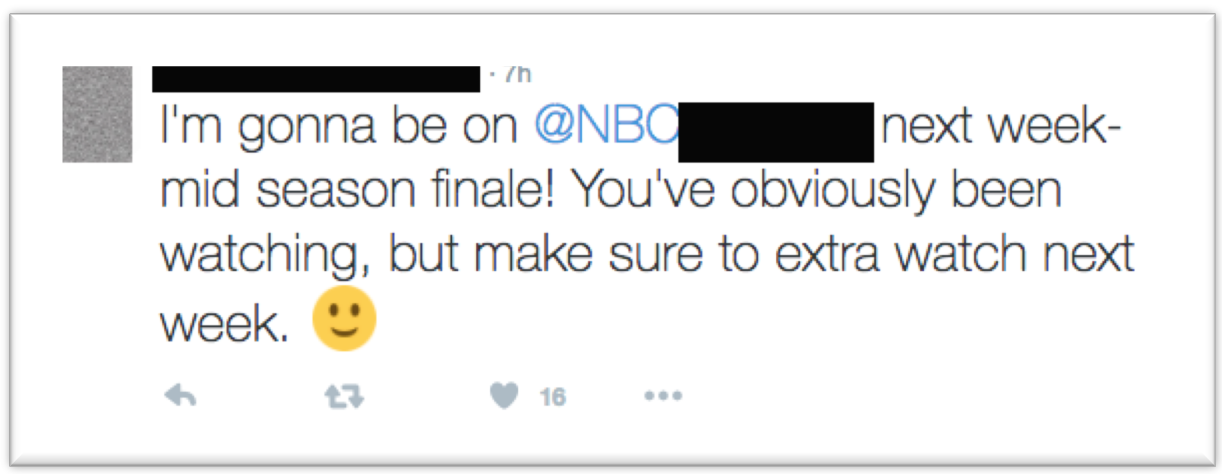

Figure 12. An actor's tweet announcing his role on a popular network TV show.

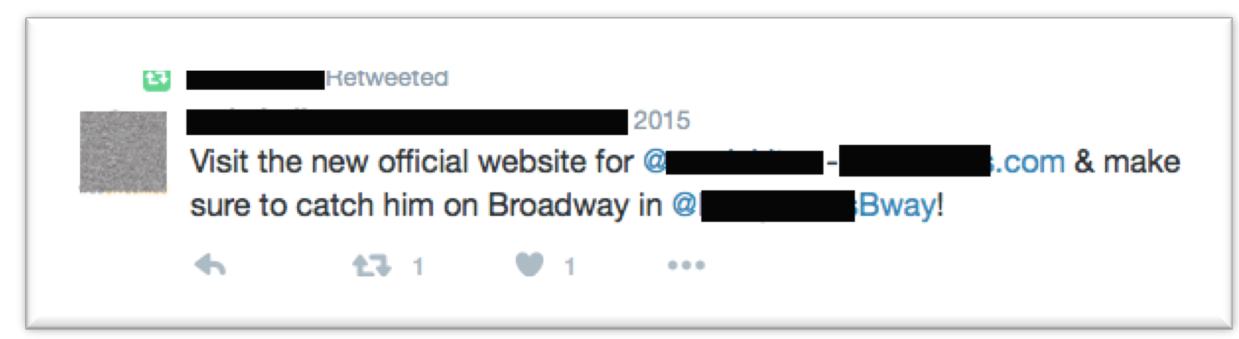

Figure 13. An actor's retweet from another Twitter account promoting his official acting website and his new role on a popular Broadway show. 


\section{CHAPTER 5}

\section{CONCLUSION}

\section{Discussion}

Based on the findings outlined above it can be determined that social media has, in fact, shifted from a space of self-expression (Joinson, 2008) and connection (boyd \& Ellison, 2007), to a place of self- promotion (Van Dijck, 2013) where people can utilize the medium like businesses do (Kietzmann et al., 2011) for the purpose of promoting a personal brand (Labrecque et al., 2011). How are Facebook and Twitter used as a tool for the creation and maintenance of the professional image? Out of the ten actors' social media pages observed an overwhelming majority of them utilized the medium for personal and professional self-promotion. A majority of the actors observed, used the social media platforms directly as a tool to promote their upcoming projects as well maintain their image as a working professional actor through the promotion of previous jobs as well as identifying their status within the field through listing employment and education information in their intro sections (See Figures $3 \& 4$ ).

How is this professional image used to form a personal brand? For an individual (in our case the actor) to build a personal brand, the online community is the premier place to accomplish this. It is considered to be the most effective medium for marketing today (Whitler, 2014). If we are to believe Bill Gates that "content is King" (Bailey, 2010), then the content that the actor puts online is imperative to his personal brand. Not only does content play a crucial role in the spread of the information (Guerini et al., 2011), but it is an important piece marketing strategy as outlined by the PESO Model. 
For example, the actor promoting his interview (Figure 11) on social media is how he utilizes the Earned and Shared elements of the model to directly promote his brand. The actor who is promoting his official website (Figure 5), the actor promoting his YouTube content (Figure 6), and the actor promoting his photography sessions (Figure 9) exemplify the action of "sharing" their "owned" media through SNS. These tactics implemented by large companies as part of their social media marketing strategies can be just as easily and effectively implemented by the individual to promote his personal brand.

Another consideration for the actor looking to promote his personal brand, is the rate at which information spreads through the internet. These concepts of word-ofmouth and virality are valuable to the marketer looking to share content online. As previously explored, the faster content spreads though a group or the larger the amount of users that see the content, the more popular the content becomes and, as a result, a direct connection to its author is made resulting in the popularity of the author as well. The best example I can think of that exemplifies this idea that content will lead to the creator is the rising popularity of Adam Ellis. The cartoonist and BuzzFeed content creator has been drawing cartoons on the internet for years (Visser, 2014). As his content becomes more and more popular, it drives viewers to his Facebook page and ultimately to his website where they can buy his merchandise. He has over 500,000 followers on Facebook and his website has experienced over 16,000,000 views. The popularity of Ellis' relatable art, has created a following for him, and ultimately a desire for supporters of his content to, ultimately, support him. 
As the actor promotes their personal brand, this does include his look or image. In the modern age where the "selfie" has become a global phenomenon (Day, 2013), I was surprised to see the lack of selfies on these actors' websites. Images of themselves taken by others were not lacking. The actors did place pictures from photo shoots or professional photography sessions, however the casual selfie that became too prominent in the modern internet social media age was surprisingly lacking. Only these professional photos and photos taken by other people or photos posted with additional people like friends, family members, and cast-mates, as well as photos with previously described pets were on the majority of Facebook pages.

Also noticeably absent from these Facebook pages is negative rhetoric. In an age when negativity runs rampant (Pfeffer, Zorback, \& Carley, 2014) on social media, there was zero negative speech or negative imagery on all ten of the participants Facebook pages that were observed. Other content, noticeably absent, involved inappropriate behavior that occasionally runs rampant on the medium (Halper, 2015). The participants did not post photos of themselves at parties or bars with excessive amounts of alcohol or partaking in questionable behavior. The overall perception of the actor is to use his or her social media pages as a tool to promote a positive and professional image. This is something that was very apparent and easily recognizable when observing all of the participants Facebook pages.

The way that actors use Facebook and Twitter as a multimedia platform is important to how well they know the different forms of media and how they use these various elements to their benefit. This is important to notice for it speaks to the actors' ability to stretch their brand to their benefit in bringing awareness to the media viewing 
public. On the Facebook and Twitter feeds observed, I noticed that status updates were in the minority. The majority of posts on both Facebook and Twitter were through shared platforms, i.e. sharing links from websites, sharing images from Instagram, sharing videos from YouTube, as well as sharing posts from Twitter on Facebook and vice versa. Instagram is a social network that has increased significantly in popularity with $32 \%$ of online users using the medium today (Greenwood et al., 2016). The ability to share pictures adds a visual element to the brand. And the ability to cross promote through multiple social networks streamlines the brand and makes for easy and fast access to each network's multiple audience base.

\section{Limitations}

The subjects of the study, the length of time spent studying them, the social media platforms observed, and the time of year all make up the limitations of this study. For a full interpretation of personal branding techniques an examination beyond one group of people is necessary. The actor, although a relevant group of people (previously described due to the fact their professions and personal lives are closely reflective of one another), is only one group of subjects. A more in-depth examination of how social media users utilize the platform to promote a personal brand could be created using a variety of subjects from different professional platforms. Marwick (2013) did this using technologists in Silicon Valley as her subjects.

Observing actors over the course of 8-10 weeks over two social media platforms (Facebook and Twitter only) limited the amount of data that could be compiled. Studying groups over a longer period of time, while examining subjects over more social media platforms like Facebook, Twitter, Instagram, Pinterest, Reddit, Snapchat, and 
others could create a larger image of personal branding, especially how the content is cross promoted over the numerous accounts.

Lastly, observing actors during an election season posed a unique problem, in that, the actor as an artists proved to be heavily involved with their political causes and beliefs. The challenge in this observation is finding an actor who isn't passionate about politics. All ten of the participants observed had some form of political expression on their Facebook pages and Twitter feeds. As I have previously mentioned Facebook has been a consistent medium for viewing, circulating, and promoting political and social opinion. According to the Pew Research Center, $66 \%$ of users view some form of political content from Facebook (Gottfried, 2014), 61\% of Millennials alone get news about politics and government from Facebook (Gottfried \& Barthel, 2015). The actor as artist uses his soapbox. As Howard Zinn (2003) reverberates in his post 9/11 book, Artists in Time of War, the job of the artist is "to think outside the boundaries of permissible thought and dare to say things that no one else will say" (Zinn, 2003). The artist is given the task of holding the mirror up to society. As Picasso once said "Art is a lie that makes us realize truth" (Zinn, 2003). For the sake of this argument, we will call the actor an artist; I think that most actors consider themselves artists. However, for this purpose, we could argue that the actor considers himself an activist as well. The promotion of progressive, forward thinking thought, is a valuable attribute to the actor's brand, and one that he heavily values.

\section{Further Research}

The two main elements of this study, the personal brand, and social media, are still early in their development as a concentration (compared to the history of 
communication research). Additional research into the personal brand can be examined through different professions as subjects. How does the subject compare within the realm of other industries? Additionally, when we examine social media, there is a larger group of platforms than Facebook and Twitter. While they are more common, it is interesting and even necessary to examine how different social networking sites play different roles in this subject of self-promotion and personal branding. How do they work together to create a complete picture of the individual who utilizes them?

As younger age groups continue to grow older and enter the mainstream workplace, and as we continue to see the percentage of online adults on social networking sites grow, the impressions put forward online by these groups will continue to play an important role in their positions offline as well. Romantic attachments, potential employment, friendships, and more will hinge on this new online personality that a person puts forth. Because of this, it is not only valuable, but necessary that we learn to be conscious of this online personality. Furthermore, it is to our benefit that we learn to use the platform as a marketing tool to put forth the best possible image of ourselves. As we are able to use the medium to our benefit, and as we use the medium to bring out the best in ourselves, we run the potential to bring out the best in others. In today's world where negativity is rampant; where conflict, and partisan views, and anger, and hate control the rhetoric seen on various media, it is the responsibility of us as individuals to use the power of this social media mass communication to promote positivity, compromise, understanding, acceptance, and love. It is by promoting these valuable and necessary uplifting characteristics of ourselves that we can come together and bring together a better story for the future. 


\section{BIBLIOGRAPHY}

Ahmad, N. S., Musa, R., \& Harun, M. H. M. (2016). The Impact of Social Media Content Marketing (SMCM) towards Brand Health. Procedia Economics and Finance, 37, 331-336.

Bailey, C. (2010, May 31). Content is King by Bill Gates. CraigBailey. Retrieved from http://www.craigbailey.net/content-is-king-by-bill-gates/

Belk, R. W. (1988). Possessions and the extended self. Journal of consumer research, 15(2), 139-168.

Berger, J., \& Milkman, K. L. (2012). What makes online content viral?. Journal of marketing research, 49(2), 192-205.

boyd, d. \& Ellison, N. B. (2007). Social network sites: Definition, history, and scholarship. Journal of Computer-Mediated Communication, 13(1), 210-230.

Brenner, J., \& Smith, A. (2013). 72\% of online adults are social networking site users. Washington, DC: Pew Internet \& American Life Project.

Brooks, A. K., \& Anumudu, C. (2016). Identity Development in Personal Branding Instruction Social Narratives and Online Brand Management in a Global Economy. Adult Learning, 27(1), 23-29.

Brown, V. R., \& Vaughn, E. D. (2011). The writing on the (Facebook) wall: The use of social networking sites in hiring decisions. Journal of Business and psychology, 26(2), 219-225.

Castronovo, C., \& Huang, L. (2012). Social media in an alternative marketing communication model. Journal of Marketing Development and Competitiveness, 6(1), 117.

Chaykowski, K. (2015, December 8). Number Of Facebook Business Pages Climbs To 50 Million With New Messaging Tools. Forbes. Retrieved from http://www.forbes.com/sites/kathleenchaykowski/2015/12/08/facebookbusiness-pages-climb-to-50-million-with-new-messagingtools/\#67e6764b1c2c

Day, E. (2013, July 13). How selfies became a global phenomenon. The Guardian, 14.

Dietrich, G. (2015, March 23). PR Pros Must Embrace the PESO Model. SpinSucks. Retrieved from http://spinsucks.com/communication/pr-pros-must-embracethe-peso-model/ 
Drury, G. (2008). Opinion piece: Social media: Should marketers engage and how can it be done effectively?. Journal of Direct, Data and Digital Marketing Practice, 9(3), 274-277.

Edosomwan, S., Prakasan, S. K., Kouame, D., Watson, J., \& Seymour, T. (2011). The history of social media and its impact on business. Journal of Applied Management and entrepreneurship, 16(3), 79.

Ellis, A. (2015, April 17). This Illustrator Perfectly Captures The Struggle Of Being A Millennial. The Huffington Post. Retrieved from http://www.huffingtonpost.com/2015/04/17/adam-ellis-really-getsit_n_7087796.html

Ellison, N., Heino, R., \& Gibbs, J. (2006). Managing impressions online: Selfpresentation processes in the online dating environment. Journal of ComputerMediated Communication, 11(2), 415-441.

Eltantawy, N., \& Wiest, J. B. (2011). The Arab spring| Social media in the Egyptian revolution: reconsidering resource mobilization theory. International Journal of Communication, 5, 18.

Erickson, C. (2012, February 29). 20 Facebook Page Cover Photos to Inspire Your Brand. Mashable. Retrieved from http://mashable.com/2012/02/29/facebooktimeline-pages-cover-photos/

Estes, A. C. (2012, October 22). 'Horses and Bayonets' Goes from Obama's Mouth to Parody Tumblr in 9 Minutes. The Atlantic. Retrieved from http:// www.theatlanticwire.com/politics/2012/10/it-took-less-30-minutes-horses-andbayonets- become-meme/58227/

Glynn, C. J., Huge, M. E., \& Hoffman, L. H. (2012). All the news that's fit to post: A profile of news use on social networking sites. Computers in Human Behavior, 28(1), 113-119.

Goffman, E. (1959). The presentation of self in everyday life Garden City. Doubleday.

Gottfried, J. (2014). Facebook and Twitter as political forums: Two different dynamics. Pew Research Center

Gottfried, J., \& Barthel, M. (2015). How Millennials' political news habits differ from those of Gen Xers and Baby Boomers. Pew Research Center Journalism and Media.

Gottfried, J., \& Shearer, E. (2016). News use across social media platforms 2016. Pew Research Center. 
Greenwood S., Perrin A., \& Duggan M. (2016) Social Media Update 2016: Facebook usage and engagement is on the rise, while adoption of other platforms holds steady. Pew Research Center

Guerini, M., Strapparava, C., \& Özbal, G. (2011, July). Exploring Text Virality in Social Networks. In ICWSM.

Halper, K. (2015, July 15). A Brief History of People Getting Fired for Social Media Stupidity: 17 of the most offensive and dumb Twitter, Facebook and Instagram fails. Rolling Stone. Retrieved from http://www.rollingstone.com/culture/lists/a-brief-history-of-people-gettingfired-for-social-media-stupidity-20150713

Holiday Shopping Goes Social. (2014, December 19). Crowdtap. Retrieved from http://blog.crowdtap.it/2014/12/holiday-shopping-goes-social-infographic/

Hudson, S., Huang, L., Roth, M. S., \& Madden, T. J. (2016). The influence of social media interactions on consumer-brand relationships: A three-country study of brand perceptions and marketing behaviors. International Journal of Research in Marketing, 33(1), 27-41.

Iliff, R. (2014, December 5). The SWOT Team Why PR is embracing the PESO model. Mashable. Retrieved from http://mashable.com/2014/12/05/publicrelations-industry/\#W2NI6gOSKOqx

Joinson, A. N. (2008, April). Looking at, looking up or keeping up with people?: motives and use of facebook. In Proceedings of the SIGCHI conference on Human Factors in Computing Systems (pp. 1027-1036). ACM.

Karaduman, İ. (2013). The effect of social media on personal branding efforts of top level executives. Procedia-Social and Behavioral Sciences, 99, 465-473.

Katz, E., Blumler, J. G., \& Gurevitch, M. (1973). Uses and gratifications research. The Public Opinion Quarterly, 37(4), 509-523.

Kietzmann, J. H., Hermkens, K., McCarthy, I. P., \& Silvestre, B. S. (2011). Social media? Get serious! Understanding the functional building blocks of social media. Business horizons, 54(3), 241-251.

Koiso-Kanttila, N. (2004). Digital content marketing: a literature synthesis. Journal of Marketing Management, 20(1-2), 45-65.

Krämer, N. C., \& Winter, S. (2008). Impression management 2.0: The relationship of self-esteem, extraversion, self-efficacy, and self-presentation within social networking sites. Journal of Media Psychology, 20(3), 106-116. 
Labrecque, L. I., Markos, E., \& Milne, G. R. (2011). Online personal branding: processes, challenges, and implications. Journal of Interactive Marketing, 25(1), 37-50.

Lair, D. J., Sullivan, K., \& Cheney, G. (2005). Marketization and the recasting of the professional self the rhetoric and ethics of personal branding. Management Communication Quarterly, 18(3), 307-343.

Mangold, W. G., \& Faulds, D. J. (2009). Social media: The new hybrid element of the promotion mix. Business horizons, 52(4), 357-365.

Marwick, A. E., \& boyd, d. (2011). To see and be seen: Celebrity practice on Twitter. Convergence: the international journal of research into new media technologies, 17(2), 139-158.

Marwick, A. E. (2013). Status update: Celebrity, publicity, and branding in the social media age. Yale University Press.

McLaughlin, J. (2011, December 21). What is a Brand, Anyway?. Forbes. Retrieved from http://www.forbes.com/sites/jerrymclaughlin/2011/12/21/what-is-abrand-anyway/\#335f41ce2aa4

Midha A. (2014, May 1). Study: Exposure to brand Tweets drives consumers to take action - both on and off Twitter. Twitter. Retrieved from https://blog.twitter.com/2014/study-exposure-to-brand-tweets-drivesconsumers-to-take-action-both-on-and-off-twitter

Mitchell, A., Kiley, J., Gottfried, J., \& Guskin, E. (2013). The role of news on Facebook: Common yet incidental. Pew Journalism Project.

Moore, K., \& Reid, S. (2008). The birth of brand: 4000 years of branding. Business History, 50(4), 419-432.

Peralta, E. (2012, October 17). Presidential Debate Spins 'Binders Full Of Women' Meme, Fact Checks. NPR. Retrieved from: http://www.npr.org/blogs/thetwoway/2012/10/17/163071667/presidential-debate-spins-binders-full-of-womenmeme

Peters, T. (1997, August 31). The Brand Called You. Fast Company. Retrieved from http://www.fastcompany.com/magazine/10/brandyou.html.

Pfeffer, J., Zorbach, T., \& Carley, K. M. (2014). Understanding online firestorms: Negative word-of-mouth dynamics in social media networks. Journal of Marketing Communications, 20(1-2), 117-128. 
Pulizzi, J. (2012). The rise of storytelling as the new marketing. Publishing research quarterly, 28(2), 116-123.

Pulizzi, J. (2016, July 1). The History of Content Marketing. Content Marketing Institute. Retrieved from http://contentmarketinginstitute.com/2016/07/historycontent-marketing/

Raacke, J., \& Bonds-Raacke, J. (2008). MySpace and Facebook: Applying the uses and gratifications theory to exploring friend-networking sites.

Cyberpsychology \& behavior, 11(2), 169-174.

Rogers, E. M. (2010). Diffusion of innovations. Simon and Schuster.

Rosenberg, J., \& Egbert, N. (2011). Online impression management: Personality traits and concerns for secondary goals as predictors of self-presentation tactics on Facebook. Journal of Computer-Mediated Communication, 17(1), 1-18.

Rowley, J. (2008). Understanding digital content marketing. Journal of marketing management, 24(5-6), 517-540.

Rubinstein, H., \& Griffiths, C. (2001). Branding matters more on the internet. Journal of Brand Management, 8(6), 394-404.

Ruggiero, T. E. (2000). Uses and gratifications theory in the 21 st century. Mass communication \& society, 3(1), 3-37.

Shadel, M. (2014, January 8). A Brief History of Branding. Convoy. Retrieved from https://www.weareconvoy.com/2014/01/a-brief-history-of-branding/

Skues, J. L., Williams, B., \& Wise, L. (2012). The effects of personality traits, selfesteem, loneliness, and narcissism on Facebook use among university students. Computers in Human Behavior, 28(6), 2414-2419.

The New York Times Customer Insight Group (2011). The Psychology of Sharing: Why Do People Share Online?. Retrieved from http://www.iab.net/media/file/POSWhitePaper.pdf

Tye, L. (2002). The father of spin: Edward L. Bernays and the birth of public relations. Macmillan.

Van Dijck, J. (2013). 'You have one identity': performing the self on Facebook and LinkedIn. Media, Culture \& Society, 35(2), 199-215.

Visser, N. (2015, April 17). This Illustrator Perfectly Captures The Struggle Of Being A Millennial. The Huffington Post. Retrieved from http://www.huffingtonpost.com/2015/04/17/adam-ellis-really-getsit_n_7087796.html 
Wayne, T. (2013, November 29). Who killed the catchphrase?. The New York Times. Retrieved from http://www.nytimes.com.

Weng, L., Menczer, F., \& Ahn, Y. Y. (2013). Virality prediction and community structure in social networks. Scientific reports, 3.

Wheeler, A. (2003). Designing brand identity: a complete guide to creating, building, and maintaining strong brands. John Wiley \& Sons.

Whitler, K. (2014, July 17). Why Word Of Mouth Marketing Is The Most Important Social Media. Forbes. Retrieved from http://www.forbes.com/sites/kimberlywhitler/2014/07/17/why-word-of-mouthmarketing-is-the-most-important-social-media/\#64eb0ff87a77

Wilson, R. E., Gosling, S. D., \& Graham, L. T. (2012). A review of Facebook research in the social sciences. Perspectives on psychological science, 7(3), 203-220.

Zhang, W., Johnson, T. J., Seltzer, T., \& Bichard, S. L. (2010). The revolution will be networked: The influence of social networking sites on political attitudes and behavior. Social Science Computer Review, 28(1), 75-92.

Zinn, H. (2003). Artists in Times of War. Seven Stories Press. 